\title{
Effect of influent substrate ratio on anammox granular sludge: performance and kinetics
}

\author{
Weiqiang Zhu $\cdot$ Jin Li $\mathbb{1} \cdot$ Huiyu Dong $\cdot$ Dan Wang $\cdot$ Peiyu Zhang
}

Received: 8 April 2017/Accepted: 25 September 2017/Published online: 27 September 2017

(C) Springer Science+Business Media B.V. 2017

\begin{abstract}
Effect of influent substrate ratio on anammox process was studied in sequencing batch reactor. Operating temperature was fixed at $35 \pm 1{ }^{\circ} \mathrm{C}$. Influent $\mathrm{pH}$ and hydraulic retention time were 7.5 and $6 \mathrm{~h}$, respectively. When influent $\mathrm{NO}_{2}{ }^{-}-\mathrm{N} / \mathrm{NH}_{4}{ }^{+}-\mathrm{N}$ was no more than 2.0, total nitrogen removal rate (TNRR) increased whereas $\mathrm{NH}_{4}{ }^{+}-\mathrm{N}$ removal rate stabilized at $0.32 \mathrm{~kg} /\left(\mathrm{m}^{3} \mathrm{~d}\right) . \Delta \mathrm{NO}_{2}{ }^{-}-\mathrm{N} / \Delta \mathrm{NH}_{4}{ }^{+}-\mathrm{N}$ increased with enhancing $\mathrm{NO}_{2}{ }^{-}-\mathrm{N} / \mathrm{NH}_{4}{ }^{+}-\mathrm{N}$. When $\mathrm{NO}_{2}{ }^{-}-\mathrm{N} / \mathrm{NH}_{4}{ }^{+}$ $\mathrm{N}$ was $4.5, \Delta \mathrm{NO}_{2}{ }^{-}-\mathrm{N} / \Delta \mathrm{NH}_{4}{ }^{+}-\mathrm{N}$ was 1.98 , which was much higher than theoretical value (1.32). The $\mathrm{IC}_{50}$ of $\mathrm{NO}_{2}{ }^{-}-\mathrm{N}$ was $289 \mathrm{mg} / \mathrm{L}$ and anammox activity was inhibited at high $\mathrm{NO}_{2}{ }^{-}-\mathrm{N} / \mathrm{NH}_{4}{ }^{+}-\mathrm{N}$ ratio. With regard to influent $\mathrm{NH}_{4}{ }^{+}-\mathrm{N} / \mathrm{NO}_{2}{ }^{-}-\mathrm{N}$, the maximum $\mathrm{NH}_{4}{ }^{+}-\mathrm{N}$ removal rate was $0.36 \mathrm{~kg} /\left(\mathrm{m}^{3} \mathrm{~d}\right)$, which occurred at the ratio of 4.0. Anammox activity was inhibited when influent $\mathrm{NH}_{4}{ }^{+}-\mathrm{N} / \mathrm{NO}_{2}{ }^{-}-\mathrm{N}$ was higher than 5.0. With influent $\mathrm{NO}_{3}{ }^{-}-\mathrm{N} / \mathrm{NH}_{4}{ }^{+}-\mathrm{N}$ of $2.5-6.5, \quad \mathrm{NH}_{4}{ }^{+}-\mathrm{N}$
\end{abstract}

W. Zhu $\cdot$ J. Li $(\varangle) \cdot$ P. Zhang

School of Environmental Science and Engineering, Qingdao University, Qingdao 266071, China

e-mail: ljin0532@126.com

H. Dong

Key Laboratory of Drinking Water Science and Technology, Research Center for Eco-environmental Sciences, University of Chinese Academy of Sciences,

Chinese Academy of Sciences, Beijing 100085, China

D. Wang

National Marine Environmental Forecasting Center, State

Oceanic Administration, Beijing 100081, China removal rate and NRR were stabilized at 0.33 and $0.40 \mathrm{~kg} /\left(\mathrm{m}^{3} \mathrm{~d}\right)$, respectively. When the ratio was higher than 6.5, nitrogen removal would be worsened. The inhibitory threshold concentration of $\mathrm{NO}_{2}{ }^{-}-\mathrm{N}$ was lower than $\mathrm{NH}_{4}{ }^{+}-\mathrm{N}$ and $\mathrm{NO}_{3}{ }^{-}-\mathrm{N}$. Anammox bacteria were more sensitive to $\mathrm{NO}_{2}{ }^{-}-\mathrm{N}$ than $\mathrm{NH}_{4}{ }^{+}-\mathrm{N}$ and $\mathrm{NO}_{3}{ }^{-}$-N. TNRR would be enhanced with increasing nitrogen loading rate, but sludge floatation occurred at high nitrogen loading shock. The HanLevenspiel could be applied to simulate nitrogen removal resulting from $\mathrm{NO}_{2}{ }^{-}-\mathrm{N}$ inhibition.

Keywords Anammox - Influent substrate ratio · Nitrogen removal performance $\cdot$ Kinetic analysis

\section{Introduction}

Nowadays, anaerobic ammonium oxidation (anammox) has been successfully applied in full-scale ammonium-rich wastewater treatment (van der Star et al. 2007). It could oxidize ammonium to $\mathrm{N}_{2}$ directly with nitrite as electron acceptor, which was very energy-saving and efficient (Carvajal-Arroyo et al. 2014a; Strous et al. 1998). Nevertheless, anammox process has not been widely applied due to low growth rate of anaerobic ammonium oxidizing bacteria (AnAOB) and many inhibitory factors such as low temperature (Zhu et al. 2017a, b), extreme pH (Li et al. 
2017) and organic carbon source (Zhu et al. 2017a, b). Besides, substrate inhibition is a significant obstacle for nitrogen removal and operation stability during anammox process (Jin et al. 2013).

Both $\mathrm{NH}_{4}{ }^{+}-\mathrm{N}$ and $\mathrm{NO}_{2}{ }^{-} \mathrm{N}$ are substrates for anammox reaction, and $\mathrm{NO}_{3}{ }^{-}-\mathrm{N}$ is the product of it. However, these three species are all inhibitors when they are at high concentrations (Aktan et al. 2012; Dapena-Mora et al. 2007; Jin et al. 2013; Lotti et al. 2012). Although efforts were made to study their thresholds and mechanisms, it was failed to achieve uniform result. Strous et al. (1999) noted that $100 \mathrm{mg} /$ $\mathrm{L} \mathrm{NO}_{2}{ }^{-} \mathrm{N}$ would completely inhibited anammox activity, and as high as $1000 \mathrm{mg} / \mathrm{L} \mathrm{NH}_{4}{ }^{+}-\mathrm{N}$ or $\mathrm{NO}_{3}{ }^{-}$$\mathrm{N}$ did not affect anammox process. However, other studies reported that inhibitory concentration of $\mathrm{NO}_{2}{ }^{-}-\mathrm{N}$ was around $280 \mathrm{mg} / \mathrm{L}$ (Isaka et al. 2007; Kimura et al. 2010). Dapena-Mora et al. (2007) indicated that $50 \%$ activity loss resulting from $\mathrm{NH}_{4}{ }^{+}-\mathrm{N}$ and $\mathrm{NO}_{3}{ }^{-}-\mathrm{N}$ were 770 and $630 \mathrm{mg} / \mathrm{L}$, respectively. Still, effect of influent substrate ratio on anammox process was studied little. As reported by Strous et al. (1998), influent substrate ratio $\left(\mathrm{NH}_{4}{ }^{+}-\mathrm{N} /\right.$ $\mathrm{NO}_{2}{ }^{-}-\mathrm{N}$ ) required by anammox process was $1: 1.32$. In order to achieve high nitrogen removal efficiency, influent substrate should be fed into anammox system with an appropriate ratio. If it deviated from the ratio, nitrogen removal performance was affected. However, it is ordinary that influent substrate fluctuates in most wastewaters. As a result, the potential negative effect result from influent substrate ratio should be studied.

In addition, kinetic analysis could predict the value which could not be acquired through experiment. It could also provide an effective tool for process control. The Haldane, Edwards, Aiba and Luong models were widely applied on substrate inhibition (Jin et al. 2013; De Prá et al. 2016). Besides, they played an important part in application and development of anammox process. However, they were not suitable to all studies (Dapena-Mora et al. 2007). As a result, much more kinetic models should be constructed and analyzed, and more information concerning effect resulting from influent substrate ratio should be revealed.

A sequencing batch reactor (SBR) presents a great simplicity and flexibility of operation, which favors the enrichment of slow-growing bacteria (Lan et al. 2011). In this work, nitrogen removal performance of anammox process was assessed in an SBR with various influent substrate ratios. Besides, kinetic analysis was performed to study the effect resulting from influent substrate ratio. Unlike single ammonia or nitrite nitrogen, influent substrate ratios on anammox granular sludge were focused on in this study. What's more, some strategies to alleviate substrate inhibition were proposed. Still, sludge floatation found at high nitrogen loading rate was explored. The results acquired from this work were also compared with previous reports.

\section{Materials and methods}

\section{Experimental set-up}

Three parallel SBRs (R1, R2 and R3) made of polymethyl methacrylate were used in this work. They were double-jacketed with an effective volume of $1.5 \mathrm{~L}$. Three reactors were all inoculated with $1.65 \mathrm{~g} / \mathrm{L}$ anammox sludge and covered completely with aluminum caps to create a dark circumstance. Temperature was maintained at $35 \pm 1{ }^{\circ} \mathrm{C}$ and hydraulic retention time was at $6 \mathrm{~h}$. Two cycles were run each day in this experiment. Complete mixing was achieved using mechanical stirrer with rotating speed of $100 \mathrm{rpm} . \mathrm{N}_{2}(99.99 \%)$ was purged into influent to maintain anaerobic condition. Each reactor was bubbled by $\mathrm{N}_{2}$ for $10 \mathrm{~min}$ before sludge was inoculated into it.

Biomass and synthetic wastewater

Inoculated sludge was obtained from a laboratoryscale reactor with working volume of $7 \mathrm{~L}$ which operated steadily over 1 year with $\mathrm{NO}_{2}{ }^{-}-\mathrm{N} / \mathrm{NH}_{4}{ }^{+}$$\mathrm{N}=1.32\left(\mathrm{NO}_{2}{ }^{-}-\mathrm{N} 105 \mathrm{mg} / \mathrm{L} ; \mathrm{NH}_{4}{ }^{+}-\mathrm{N} 80 \mathrm{mg} / \mathrm{L}\right)$ at $35 \pm 1{ }^{\circ} \mathrm{C}$. Both $\mathrm{NO}_{2}{ }^{-}-\mathrm{N}$ and $\mathrm{NH}_{4}{ }^{+}-\mathrm{N}$ could be completely removed. The diameter of granular biomass was $0.5-5.0 \mathrm{~mm}$, with a mean value of $1.7 \mathrm{~mm}$. The digital and microscopic images of the sludge were presented in Fig. $1 . \mathrm{NH}_{4}{ }^{+}-\mathrm{N}, \mathrm{NO}_{2}{ }^{-}-\mathrm{N}$ and $\mathrm{NO}_{3}{ }^{-}-\mathrm{N}$ were added into reactors as required in the form of $\mathrm{NH}_{4} \mathrm{Cl}, \mathrm{NaNO}_{2}$ and $\mathrm{KNO}_{3}$, respectively. The composition of synthetic wastewater was $\mathrm{KH}_{2} \mathrm{PO}_{4}$ $0.028 \mathrm{~g} / \mathrm{L}, \mathrm{CaCl}_{2} 0.14 \mathrm{~g} / \mathrm{L}, \mathrm{KHCO}_{3} 2.0 \mathrm{~g} / \mathrm{L}$ and $\mathrm{MgSO}_{4} \cdot 7 \mathrm{H}_{2} \mathrm{O} 0.2 \mathrm{~g} / \mathrm{L}$. Trace element solutions I and II (1.2 mL per liter medium) were also added into 

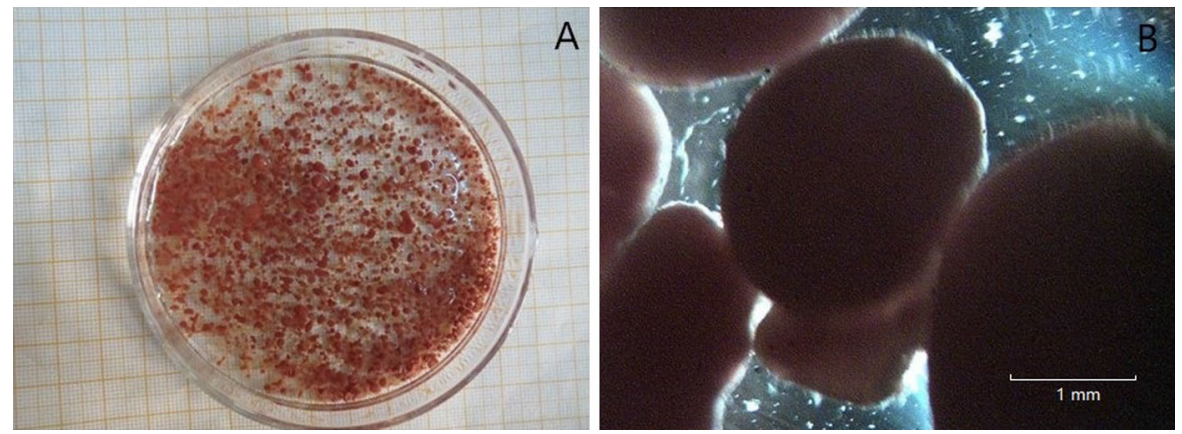

Fig. 1 Image of inoculated granular sludge

reactor as previously reported (van de Graaf et al. 1996). Influent $\mathrm{pH}$ was around $7.5 \pm 0.1$.

\section{Operational strategy}

The effect resulting from influent $\mathrm{NO}_{2}{ }^{-}-\mathrm{N} / \mathrm{NH}_{4}{ }^{+}-\mathrm{N}$ was carried out in R1. During this period, influent $\mathrm{NH}_{4}{ }^{+}-\mathrm{N}$ was stabilized at $80 \mathrm{mg} / \mathrm{L}$, whereas influent $\mathrm{NO}_{2}{ }^{-}-\mathrm{N}$ was added according to $\mathrm{NO}_{2}{ }^{-}-\mathrm{N} / \mathrm{NH}_{4}{ }^{+}-\mathrm{N}$ which ranged from 1.32 to 4.5 . Effect resulting from influent $\mathrm{NH}_{4}{ }^{+}-\mathrm{N} / \mathrm{NO}_{2}{ }^{-}-\mathrm{N}$ was carried out in $\mathrm{R} 2$. At this period, $\mathrm{NO}_{2}{ }^{-} \mathrm{N}$ concentration in influent was stabilized at $105 \mathrm{mg} / \mathrm{L}$, whereas $\mathrm{NH}_{4}{ }^{+}-\mathrm{N}$ added in influent was based on $\mathrm{NH}_{4}{ }^{+}-\mathrm{N} / \mathrm{NO}_{2}{ }^{-}-\mathrm{N}$ which ranged from 1/1.32 to 7.0. Still, the effect resulting from influent $\mathrm{NO}_{3}{ }^{-} \mathrm{N} / \mathrm{NH}_{4}{ }^{+}-\mathrm{N}$ was performed in $\mathrm{R} 3$. During this period, both $\mathrm{NH}_{4}{ }^{+}-\mathrm{N}$ and $\mathrm{NO}_{2}{ }^{-}-\mathrm{N}$ concentration in influent were 80 and $105 \mathrm{mg} / \mathrm{L}$, respectively, whereas the $\mathrm{NO}_{3}{ }^{-} \mathrm{N}$ added in influent was based on $\mathrm{NO}_{3}{ }^{-}-\mathrm{N} / \mathrm{NH}_{4}{ }^{+}-\mathrm{N}$ which ranged from 0 to 9.5. When influent $\mathrm{NO}_{2}{ }^{-}-\mathrm{N} / \mathrm{NH}_{4}{ }^{+}-\mathrm{N}$ test was finished in $\mathrm{R} 1$, influent $\mathrm{NO}_{2}{ }^{-}-\mathrm{N}$ decreased to $105 \mathrm{mg} / \mathrm{L}$ $\left(\mathrm{NO}_{2}{ }^{-}-\mathrm{N} / \mathrm{NH}_{4}{ }^{+}-\mathrm{N}=1.32\right)$. Then $\mathrm{NH}_{4}{ }^{+}-\mathrm{N}$ and $\mathrm{NO}_{2}{ }^{-}-\mathrm{N}$ increased simultaneously and effect resulting nitrogen loading shock was explored.

Kinetic analysis

\section{Substrate inhibition model}

To demonstrate nitrite inhibition on anammox performance quantitatively, Haldane (Eq. 1), Aiba (Eq. 2) and Edwards (Eq. 3) models were applied in this work to predict substrate inhibition on anammox process (Aiba et al. 1968; Edwards 1970; Jin et al. 2013). In addition, Luong, Han-Levenspiel and Tseng-Wayman models were also used in present research. Akaike information criterion (AIC) and F-Value were employed to evaluate model appropriateness.

$$
\begin{aligned}
& r=\frac{r_{\max } S}{K_{S}+S+S^{2} / K_{I H}} \\
& r=\frac{r_{\max } S}{K_{S}+S} \exp \left(-\frac{S}{K_{I A}}\right) \\
& r=r_{\max }\left(\exp \left(-\frac{S}{K_{I E}}\right)-\exp \left(-\frac{S}{K_{S}}\right)\right)
\end{aligned}
$$

Luong (1987) proposed a substrate inhibition model (Eq. 4) which was applied in yeast growth. However, it was first used in anammox system in this work.

$\mathrm{r}=\frac{\mathrm{r}_{\mathrm{max}} \mathrm{S}}{\mathrm{K}_{\mathrm{S}}+\mathrm{S}}\left(1-\frac{\mathrm{S}}{\mathrm{S}_{\mathrm{m}}}\right)^{\mathrm{n}}$

Han and Levenspiel (1988) introduced the model (Eq. 5) which was applied in the growth of a mixed culture with n-pentane. Though it was seldom to used in anammox process, it fitted the experimental data well (Niu et al. 2016).

$\mathrm{r}=\mathrm{r}_{\max } \mathrm{S} \frac{1-\left(\mathrm{S} / \mathrm{S}_{\mathrm{m}}\right)^{\mathrm{n}}}{\mathrm{S}+\mathrm{K}_{\mathrm{S}}\left(1-\mathrm{S} / \mathrm{S}_{\mathrm{m}}\right)^{\mathrm{m}}}$

The Tseng-Wayman model (Eq. 6) was proposed by Tseng and Wayman (1975) and it was used to describe inhibitory effect resulting from gluconic acid and glucose on Gluconobacter quantitatively.

$\mathrm{r}=\mathrm{r}_{\max }\left[\frac{\mathrm{S}}{\mathrm{S}+\mathrm{K}_{\mathrm{S}}}\right]-\mathrm{K}_{\mathrm{IT}}\left(\mathrm{S}-\mathrm{S}_{\text {crit }}\right)$

where $r$ is substrate removal rate $\left[\mathrm{kg} /\left(\mathrm{m}^{3} \mathrm{~d}\right)\right] ; r_{\max }$ is maximum substrate removal rate $\left[\mathrm{kg} /\left(\mathrm{m}^{3} \mathrm{~d}\right)\right]$; $\mathrm{S}$ is substrate concentration $(\mathrm{mg} / \mathrm{L}) ; \mathrm{S}_{\mathrm{m}}$ is substrate 
concentration above which net growth ceases; $\mathrm{S}_{\text {crit }}$ is threshold substrate concentration; $\mathrm{K}_{\mathrm{S}}$ is half-saturation coefficient $(\mathrm{mg} / \mathrm{L}) ; \mathrm{K}_{\mathrm{IH}}$ is Haldane inhibition coefficient (mg/L); $\mathrm{K}_{\mathrm{IA}}$ is Aiba inhibition coefficient $(\mathrm{mg} / \mathrm{L}) ; \mathrm{K}_{\mathrm{IE}}$ is Edwards inhibition coefficient $(\mathrm{mg} / \mathrm{L})$; $\mathrm{K}_{\mathrm{IT}}$ is Tseng-Wayman inhibition coefficient $(\mathrm{mg} / \mathrm{L})$; $\mathrm{n}$ and $\mathrm{m}$ are coefficients.

\section{Modified non-competition inhibition model}

$\mathrm{IC}_{50}$ (concentration causing a 50\% inhibition) of noncompetition inhibitor could be calculated using modified non-competitive inhibition model (Kroiss et al. 1992) (Eq. 7).

$\mathrm{I}(\%)=100\left(1-\frac{1}{1+(\mathrm{S} / \mathrm{a})^{\mathrm{b}}}\right)$

where $\mathrm{I}(\%)$ is inhibition ratio (\%); $\mathrm{S}$ is inhibitor concentration $(\mathrm{mg} / \mathrm{L})$; a is $\mathrm{IC}_{50}$ of the inhibitor $(\mathrm{mg} / \mathrm{L})$; $\mathrm{b}$ is fitting parameter.

Analytical methods

Influent and effluent samples were collected and analyzed immediately. $\mathrm{NH}_{4}{ }^{+}-\mathrm{N}, \mathrm{NO}_{2}{ }^{-}-\mathrm{N}$ and $\mathrm{NO}_{3}{ }^{-}$$\mathrm{N}$ concentrations were analyzed according to standard methods (APHA 1998). Temperature and $\mathrm{pH}$ were measured by WTW 340i/SET pH/Oxi portable multi parameter measuring meter. Sludge concentration was measured after filtering the washed samples through $0.45 \mu \mathrm{m}$ membrane filter and drying at $105{ }^{\circ} \mathrm{C}$ to constant weight. Granular sludge size was calculated by image analysis using software Nano-Measurer 1.2. Each data point represented in present research was the mean value of three replicates, and standard deviation was lower than $10 \%$ of the mean value.

\section{Results and discussion}

Performance of anammox process with different influent substrate ratios.

\section{Influent $\mathrm{NO}_{2}{ }^{-}-\mathrm{N} \mathrm{NH}_{4}{ }^{+}-\mathrm{N}$}

Nitrogen removal performance of $\mathrm{R} 1$ was presented in Fig. 2. With influent $\mathrm{NO}_{2}{ }^{-}-\mathrm{N} / \mathrm{NH}_{4}{ }^{+}-\mathrm{N}$ no more than 2.0, total nitrogen removal rate (TNRR) increased whereas ammonium removal rate (ARR) stabilized at $0.32 \mathrm{~kg} /\left(\mathrm{m}^{3} \mathrm{~d}\right)$. When the ratio increased from 2.0 to 4.5, both TNRR and ARR decreased gradually. TNRR and ARR were 0.15 and $0.06 \mathrm{~kg} /\left(\mathrm{m}^{3} \mathrm{~d}\right)$, respectively, when the ratio was 4.5. Anammox activity was inhibited at high $\mathrm{NO}_{2}{ }^{-}-\mathrm{N} / \mathrm{NH}_{4}{ }^{+}-\mathrm{N}$ ratio. Tao et al. (2012) indicated that $\mathrm{NO}_{2}^{-}-\mathrm{N}^{-} \mathrm{NH}_{4}{ }^{+}-\mathrm{N}$ higher than 1.5 might negatively inhibit anammox process. Simulated $\mathrm{IC}_{50}$ of nitrite through modified non-competition inhibition model was $289 \mathrm{mg} / \mathrm{L}$ in present research. It was higher than Strous et al. (1999) and Egli et al. (2001) who found nitrite inhibition threshold values were 100 and $185 \mathrm{mg} / \mathrm{L}$, respectively. However, it was lower than Cho et al. (2010) and Fernandez et al. (2012) who indicated $\mathrm{IC}_{50}$ value were 400 and $350 \mathrm{mg} / \mathrm{L}$. The anammox activity comparison resulting from nitrite effect was presented in Table 1. The discrepancy between present work and early studies might be attributed to different influent ammonium loading rate, operational duration time, reactor configuration and operational mode. In addition, different Anammox species also had different inhibition threshold. Therefore, the inhibition levels might vary depending on the dominant species.

In terms of stoichiometric ratio, $\Delta \mathrm{NO}_{2}{ }^{-}-\mathrm{N} / \Delta \mathrm{NH}_{4}{ }^{+}$$\mathrm{N}$ increased with enhancing $\mathrm{NO}_{2}{ }^{-}-\mathrm{N} / \mathrm{NH}_{4}{ }^{+}-\mathrm{N}$ ratio. When $\mathrm{NO}_{2}{ }^{-}-\mathrm{N} / \mathrm{NH}_{4}{ }^{+}-\mathrm{N}$ was $4.5, \Delta \mathrm{NO}_{2}{ }^{-}-\mathrm{N} / \Delta \mathrm{NH}_{4}{ }^{+}$$\mathrm{N}$ was 1.98 , which was much higher than theoretical value (1.32). It indicated that over-consumption of nitrite occurred when nitrite surplus existed during anammox process. This did not agree with previous report (Aktan et al. 2012). Different reactor type and operation mode might devote to the discrepancy. $\Delta \mathrm{NO}_{3}{ }^{-}-\mathrm{N} / \Delta \mathrm{NH}_{4}{ }^{+}-\mathrm{N}$ also increased with enhancing $\mathrm{NO}_{2}{ }^{-}-\mathrm{N} / \mathrm{NH}_{4}{ }^{+}-\mathrm{N}$ ratio. When $\mathrm{NO}_{2}{ }^{-}-\mathrm{N} / \mathrm{NH}_{4}{ }^{+}-\mathrm{N}$ was $4.5, \Delta \mathrm{NO}_{3}{ }^{-}-\mathrm{N} / \Delta \mathrm{NH}_{4}{ }^{+}-\mathrm{N}$ was 0.68 , which was much higher than theoretical value (0.26). That meant each mole ammonium removal was accompanied by more nitrate production at high $\mathrm{NO}_{2}{ }^{-}-\mathrm{N} / \mathrm{NH}_{4}{ }^{+}-\mathrm{N}$. The change tendency of $\Delta \mathrm{NO}_{2}{ }^{-}-\mathrm{N} / \Delta \mathrm{NH}_{4}{ }^{+}-\mathrm{N}$ and $\Delta \mathrm{NO}_{3}{ }^{-}-\mathrm{N} / \Delta \mathrm{NH}_{4}{ }^{+}-\mathrm{N}$ was closed to Lotti et al. (2012) who indicated that $\Delta \mathrm{NO}_{2}{ }^{-} \mathrm{-N} / \Delta \mathrm{NH}_{4}{ }^{+}-\mathrm{N}$ and $\Delta \mathrm{NO}_{3}{ }^{-}-\mathrm{N} / \Delta \mathrm{NH}_{4}{ }^{+}-\mathrm{N}$ increased to 2.97 and 0.75 , respectively, with $3000 \mathrm{mg} / \mathrm{L} \mathrm{NO}_{2}{ }^{-}-\mathrm{N}$. In addition, the result also agreed with Strous et al. (1999) that $\Delta \mathrm{NO}_{2}{ }^{-}-\mathrm{N} / \Delta \mathrm{NH}_{4}{ }^{+}-\mathrm{N}$ increased from 1.3 at $140 \mathrm{mg} / \mathrm{L}$ $\mathrm{NO}_{2}{ }^{-}-\mathrm{N}$ to 4.0 at $700 \mathrm{mg} / \mathrm{L} \mathrm{NO}_{2}{ }^{-}-\mathrm{N}$. van Hulle et al. (2010) hold the point that electron donor of AnAOB did not limited in $\mathrm{NH}_{4}{ }^{+}-\mathrm{N}$, and other internal electron 
Fig. 2 Nitrogen removal performance with different influent $\mathrm{NO}_{2}{ }^{-}-\mathrm{N} / \mathrm{NH}_{4}{ }^{+}-\mathrm{N}$ : a concentrations of three nitrogen species in influent and effluent; $\mathbf{b}$ nitrogen removal efficiency; c loading and removal rates of $\mathrm{NH}_{4}{ }^{+}-\mathrm{N}$ and $\mathrm{NO}_{2}{ }^{-}-\mathrm{N}$; d stoichiometric ratio. (Color figure online)
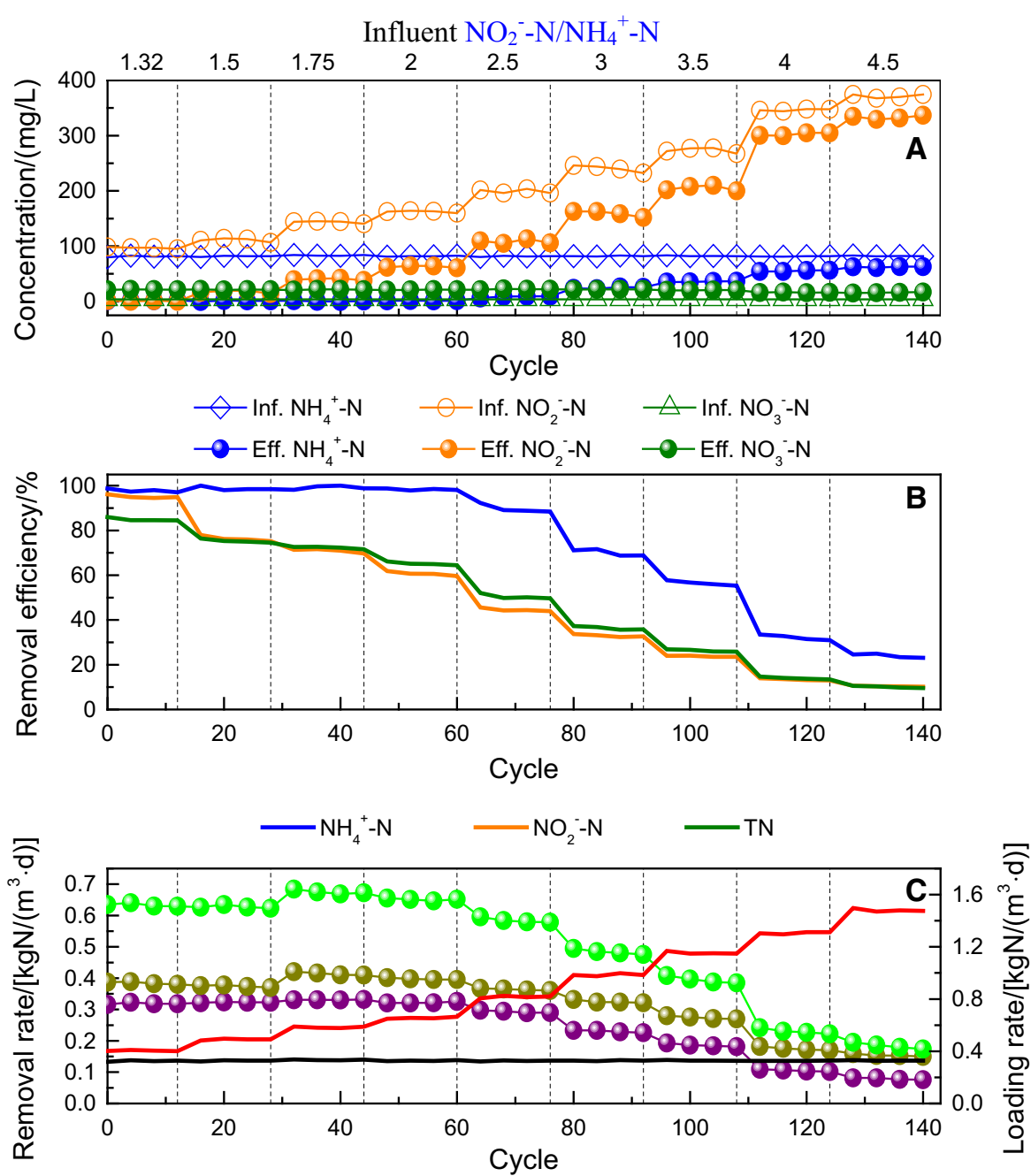

$-\mathrm{NH}_{4}^{+}-\mathrm{N}$ loading rate $-\mathrm{NO}_{2}^{-}-\mathrm{N}$ loading rate

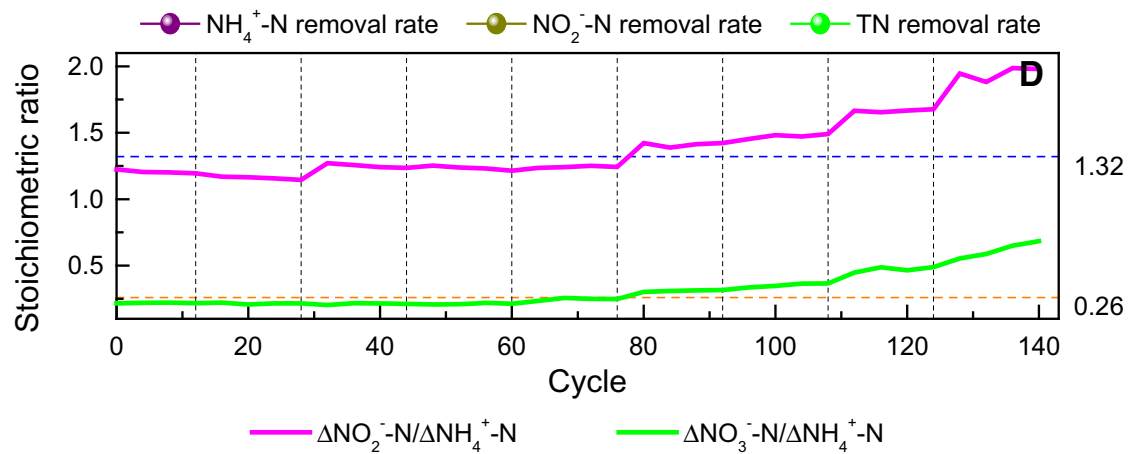

donor might generate in cell to reduce nitrite at high nitrite concentration. The ammonification of organic nitrogen derived from cell lysis (Bettazzi et al. 2010) as well as survival of heterotrophic bacteria in anammox system (Wang et al. 2016) could also devoted to increase of $\Delta \mathrm{NO}_{2}{ }^{-}-\mathrm{N} / \Delta \mathrm{NH}_{4}{ }^{+}-\mathrm{N}$ and $\Delta \mathrm{NO}_{3}{ }^{-}-\mathrm{N} / \Delta \mathrm{NH}_{4}{ }^{+}-\mathrm{N}$.

When influent $\mathrm{NO}_{2}{ }^{-}-\mathrm{N} / \mathrm{NH}_{4}{ }^{+}-\mathrm{N}$ decreased back to 1.32, anammox activity recovered with 8 cycles' operation (data not shown). This indicated that nitrite 
Table 1 Comparison of anammox activity resulting from $\mathrm{NO}_{2}{ }^{-}-\mathrm{N}$ effect

\begin{tabular}{|c|c|c|c|c|c|}
\hline Reactor & Operation mode & $\mathrm{T}\left({ }^{\circ} \mathrm{C}\right) / \mathrm{pH}$ & $\mathrm{NO}_{2}^{-} \mathrm{N} /(\mathrm{mg} / \mathrm{L})$ & Inhibition/\% & References \\
\hline Vials & Batch tests & $30 / 7.8$ & 350 & -50 & Dapena-Mora et al. (2007) \\
\hline Up-flow column & Continuous & $(33 \pm 1) /-$ & 465 & No inhibition & Yang et al. (2011) \\
\hline Up-flow column & Continuous & $(23 \pm 2) /-$ & 436 & No inhibition & Yang et al. (2011) \\
\hline UASB & Continuous & $(35 \pm 1) / 6.8$ & 280 & Inhibition & Tang et al. (2010) \\
\hline UBF & Continuous & $(35 \pm 1) /(6.8-7.0)$ & 380 & Inhibition & Tang et al. (2009) \\
\hline Vessels & Batch & $35 /-$ & $>60$ & Inhibition & Bettazzi et al. (2010) \\
\hline Monod test tubes & Batch & $36 /-$ & 274 & Inhibition & Kimura et al. (2010) \\
\hline Cylindrical reactor & Continuous & $30 /-$ & 750 & -90 & Kimura et al. (2010) \\
\hline $\mathrm{ABF}$ & Continuous & $37 /-$ & 280 & Inhibition & Isaka et al. (2007) \\
\hline Serum bottles & Batch & $37 / 7$ & 185 & -100 & Egli et al. (2001) \\
\hline Vials & Batch & $30 / 7.5$ & 400 & -50 & Lotti et al. (2012) \\
\hline Serum flasks & Batch & $(30 \pm 2) /(7.4-7.5)$ & 210 & -100 & Carvajal-Arroyo et al. (2013) \\
\hline SBR & - & - & 100 & -100 & Strous et al. (1999) \\
\hline Serum flasks & Batch & $(30 \pm 2) /(7.1-7.2)$ & $53 / 100^{\mathrm{a}}$ & $-50 /-100$ & Carvajal-Arroyo et al. (2014a) \\
\hline Serum flasks & Batch & $(30 \pm 2) /(7.1-7.2)$ & $384 / 500$ & $-50 /-100$ & Carvajal-Arroyo et al. (2014a) \\
\hline Serum vials & Batch & $37 / 7.8$ & 224 & -50 & Oshiki et al. (2011) \\
\hline UBF & Continuous & $(30 \pm 1) /-$ & 420 & No inhibition & Jin et al. (2013) \\
\hline EGSB & Continuous & $(35 \pm 1) /(6.8-7.0)$ & 768 & -24 & Chen et al. (2011) \\
\hline SBR & Batch & $35 /(7.6-7.7)$ & 500 & $-39^{\mathrm{b}}$ & Scaglione et al. (2012) \\
\hline SBR & Batch & $35 /(7.6-7.7)$ & $<175$ & $-50^{\mathrm{c}}$ & Scaglione et al. (2012) \\
\hline Serum flasks & Batch & $(30 \pm 2) / 7.2$ & 100 & $-100^{\mathrm{a}}$ & Carvajal-Arroyo et al. (2014b) \\
\hline Serum flasks & Batch & $(30 \pm 2) / 7.5$ & 100 & Mild inhibition & Carvajal-Arroyo et al. (2014b) \\
\hline Serum flacks & Batch & $35 / 7.9$ & $>300^{\mathrm{d}}$ & Inhibition & Zhang et al. (2016) \\
\hline Up-flow fixed-bed & Continuous & $34 /$ & $500^{\mathrm{e}}$ & No inhibition & Aktan et al. (2012) \\
\hline Serum bottles & Batch & $37 /-$ & $>250^{f}$ & Inhibition & Cho et al. (2010) \\
\hline Serum bottles & Batch & $37 /-$ & $<400^{\mathrm{g}}$ & No inhibition & Cho et al. (2010) \\
\hline SBR & Continuous & $35 / 7.5$ & 289 & -50 & Present research \\
\hline
\end{tabular}

$U A S B$ upflow anaerobic sludge blanket reactor, $U B F$ up-flow biofilm reactor, $A B F$ anaerobic biological filtrated reactor, $R B C$ rotating biological contactor, $S B R$ sequencing batch reactor

${ }^{\mathrm{a}} \mathrm{AnAOB}$ was pre-exposed to nitrite in absence of ammonium

${ }^{\mathrm{b}}$ Short exposure time was 3-4 h

${ }^{\mathrm{c}}$ Exposure time was prolonged to $24 \mathrm{~h}$

${ }^{\mathrm{d}}$ The inhibitory threshold concentration

${ }^{\mathrm{e}}$ The threshold concentration of $\mathrm{NH}_{4}{ }^{+}-\mathrm{N}$ inhibition

${ }^{\mathrm{f}}$ The granular anammox biomass

${ }^{\mathrm{g}}$ The homogenized biomass

inhibition was reversible process, which was in agreement with previous reports (Carvajal-Arroyo et al. 2014b; Fernandez et al. 2012; Jin et al. 2013). However, some other scholars still thought that nitrite inhibition on anammox process was irreversible (Egli et al. 2001; Jetten et al. 2005). As reported by Lotti et al. (2012), the difference was resulted from inhibition degree on AnAOB. Reversible inhibition meant a reversible decrease of catabolic activity in presence of nitrite, while irreversible inhibition referred to physical damage to cell. As a result, the physical characteristics of AnAOB in present research 
did not changed and the activity could quickly restore with low $\mathrm{NO}_{2}^{-}-\mathrm{N} / \mathrm{NH}_{4}{ }^{+}-\mathrm{N}$.

With regard to the mechanism result from nitrite inhibition on anammox activity, there was no unified result. Philips et al. (2002) stated that formation of toxic nitrite derivative occurred in reactor. The reactive derivatives (e.g. $\mathrm{NO}, \mathrm{NO}_{2}$ and $\mathrm{ONOO}-$ ) were toxic to enzyme proteins, lipids and DNA (Mehl et al. 1999). Apart from byproducts, inorganic carbon limitation and function inhibition of cell organelle were also regarded as reasons for anammox activity loss (Lotti et al. 2012). In addition, many studies considered that free nitrous acid (FNA) was the key inhibitor (Egli et al. 2001; Jaroszynski et al. 2011). FNA could act as a protonophore at high concentration, which caused inhibition through interfering trans-membrane proton gradient in AnAOB (Carvajal-Arroyo et al. 2014b). Besides, it could pass through membrane via passive diffusion due to hydrophobic group (Almeida et al. 1995). However, recent study revealed that nitrite concentration regulated inhibition level and FNA was not responsible for inhibition (Lotti et al. 2012).

When nitrite was excessive in wastewater, strategies to alleviate inhibition were needed. Firstly, addition of anammox intermediates [e.g. hydrazine $\left(\mathrm{N}_{2} \mathrm{H}_{4}\right)$ or hydroxylamine $\left.\left(\mathrm{NH}_{2}-\mathrm{OH}\right)\right]$ was proved to be effective method to restore anammox activity (Bettazzi et al. 2010; Carvajal-Arroyo et al. 2013). Secondly, sufficient inorganic carbon source in reaction system was another strategy (Yang et al. 2011). The addition of inorganic carbon source would accelerate removal rate of $\mathrm{NH}_{2}-\mathrm{OH}$ which led to accumulation of $\mathrm{N}_{2} \mathrm{H}_{4}$. Thirdly, embedding AnAOB into gel carriers would enhance the stress resistance of it (Kimura et al. 2010). Besides, nitrite inhibition could be greatly relieved by bio-film (Cho et al. 2010). Fourthly, AnAOB could be reactivated by addition of exogenous $\mathrm{NO}_{3}{ }^{-}-\mathrm{N}$ if it was severely stressed by $\mathrm{NO}_{2}{ }^{-}-\mathrm{N}$ ( $\mathrm{Li}$ et al. 2016). Exogenous $\mathrm{NO}_{3}{ }^{-}-\mathrm{N}$ could promote a secondary transport system used by AnAOB to alleviate $\mathrm{NO}_{2}{ }^{-} \mathrm{N}$ inhibition. Fifthly, as reported by Cho et al. (2010), the granular anammox biomass would tolerate higher nitrite concentration (400 mg/L) than homogenized biomass $(200 \mathrm{mg} / \mathrm{L})$. In addition, the mildly alkaline $\mathrm{pH}$ value was beneficial for AnAOB to tolerate nitrite inhibition (Carvajal-Arroyo et al. 2014b). Cells were severely affected when exposed to nitrite at acidic $\mathrm{pH}$ value, and it could tolerate nitrite at the $\mathrm{pH}$ range of 7.4-7.8.

Influent $\mathrm{NH}_{4}{ }^{+}-\mathrm{N} \mathrm{NO}_{2}{ }^{-}-\mathrm{N}$

Nitrogen removal performance of $\mathrm{R} 2$ was presented in Fig. 3. With increasing $\mathrm{NH}_{4}{ }^{+}-\mathrm{N}^{-} \mathrm{NO}_{2}{ }^{-} \mathrm{-N}$ (from $1 / 1.32$ to 5.0), nitrite removal rate (NRR) was stabilized at $0.41 \mathrm{~kg} /\left(\mathrm{m}^{3} \mathrm{~d}\right) . \mathrm{NH}_{4}{ }^{+}-\mathrm{N}$ was over-consumed in $\mathrm{R} 2$ when excessive $\mathrm{NH}_{4}{ }^{+}-\mathrm{N}$ was added. Previous studies reported that more $\mathrm{NH}_{4}{ }^{+}-\mathrm{N}$ would be converted to $\mathrm{N}_{2} \mathrm{H}_{4}$ when influent $\mathrm{NH}_{4}{ }^{+}-\mathrm{N}$ was excessive (Jin et al. 2013; Strous et al. 1999). The maximum ARR occurred at influent $\mathrm{NH}_{4}{ }^{+}-\mathrm{N} / \mathrm{NO}_{2}{ }^{-} \mathrm{N}$ of 4.0 , peaking at $0.36 \mathrm{~kg} /\left(\mathrm{m}^{3} \mathrm{~d}\right)$. With $\mathrm{NH}_{4}{ }^{+}-\mathrm{N}$ added further, both ARR and NRR decreased. When the ratio approached to 7.0 , they were 0.15 and $0.14 \mathrm{~kg}$ / $\left(\mathrm{m}^{3} \mathrm{~d}\right)$, respectively. It demonstrated that anammox activity was inhibited when influent $\mathrm{NH}_{4}{ }^{+}-\mathrm{N} / \mathrm{NO}_{2}{ }^{-}-\mathrm{N}$ was higher than 5.0.

Through the non-competition inhibition model, $\mathrm{IC}_{50}$ value of $786 \mathrm{mg} / \mathrm{L}$ was acquired. It was similar with the result reported by Dapena-Mora et al. (2007). The anammox activity comparison resulting from $\mathrm{NH}_{4}{ }^{+}-\mathrm{N}$ effect was presented in Table 2 . The inhibition degree was different from previous studies. Different $\mathrm{pH}$ and temperature not only affected AnAOB activity directly, but also inhibited anammox process indirectly through changing FA concentration. Anammox system in this work was more sensitive to ammonium than previous reports (Aktan et al. 2012; Tang et al. 2010). Different reactor configurations could result in it. SBR was used in this work and $\mathrm{H}^{+}$ was consumed during the process. As a result, $\mathrm{pH}$ would increase within a cycle and high $\mathrm{pH}$ inhibited anammox activity.

With regard to stoichiometric analysis, $\Delta \mathrm{NO}_{2}{ }^{-}-\mathrm{N} /$ $\Delta \mathrm{NH}_{4}{ }^{+}-\mathrm{N}$ slightly decreased with increasing $\mathrm{NH}_{4}{ }^{+}$$\mathrm{N} / \mathrm{NO}_{2}{ }^{-}-\mathrm{N}$. When influent $\mathrm{NH}_{4}{ }^{+}-\mathrm{N} / \mathrm{NO}_{2}{ }^{-}-\mathrm{N}$ was 7.0 , $\Delta \mathrm{NO}_{2}{ }^{-}-\mathrm{N} / \Delta \mathrm{NH}_{4}{ }^{+}-\mathrm{N}$ decreased to 0.92 . As reported by Tsushima et al. (2007), AnAOB could convert some $\mathrm{NH}_{4}{ }^{+}-\mathrm{N}$ to $\mathrm{NO}_{2}{ }^{-}-\mathrm{N}$, which devoted to dropping $\Delta \mathrm{NO}_{2}{ }^{-}-\mathrm{N} / \Delta \mathrm{NH}_{4}{ }^{+}-\mathrm{N}$. However, the result did not agree with Aktan et al. (2012) who indicated $\Delta \mathrm{NO}_{2}{ }^{-}$$\mathrm{N} / \Delta \mathrm{NH}_{4}{ }^{+}-\mathrm{N}$ did not change with increasing $\mathrm{NH}_{4}{ }^{+}-\mathrm{N} /$ $\mathrm{NO}_{2}{ }^{-}-\mathrm{N}$ in an up-flow fixed-bed reactor. In terms of $\Delta \mathrm{NO}_{3}{ }^{-}-\mathrm{N} / \Delta \mathrm{NH}_{4}{ }^{+}-\mathrm{N}$, it slightly increased with dropping $\mathrm{NH}_{4}{ }^{+}-\mathrm{N} / \mathrm{NO}_{2}{ }^{-}-\mathrm{N}$. This was also consistent with previous report from Lotti et al. (2012) who found that 
Fig. 3 Nitrogen removal performance with different influent $\mathrm{NH}_{4}{ }^{+}-\mathrm{N} / \mathrm{NO}_{2}{ }^{-}-\mathrm{N}$ : a concentrations of three nitrogen species in influent and effluent; $\mathbf{b}$ nitrogen removal efficiency; c loading and removal rates of $\mathrm{NH}_{4}{ }^{+}-\mathrm{N}$ and $\mathrm{NO}_{2}{ }^{-}-\mathrm{N}$; d stoichiometric ratio. (Color figure online)
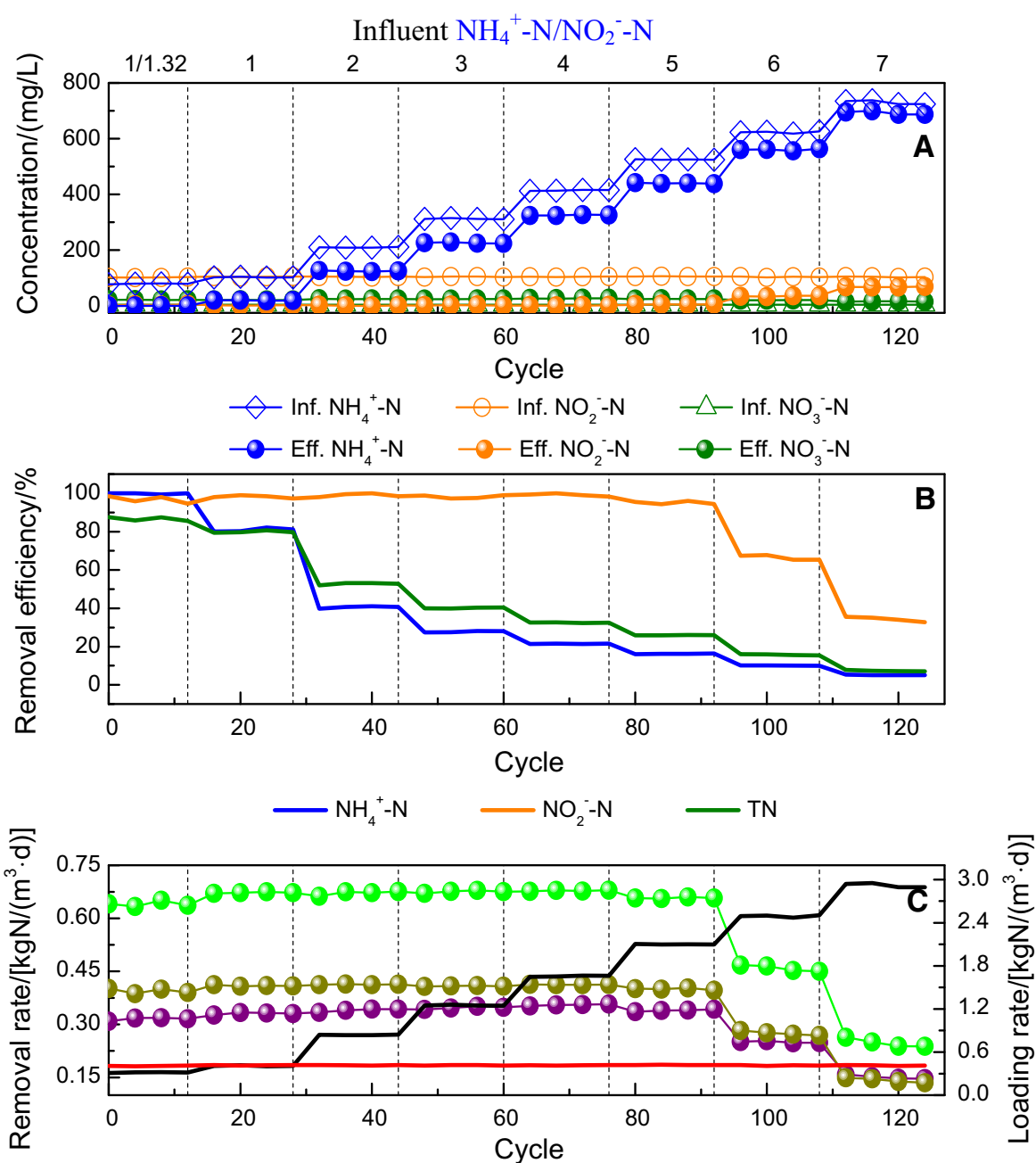

$-\mathrm{NH}_{4}^{+}-\mathrm{N}$ loading rate $-\mathrm{NO}_{2}^{-}-\mathrm{N}$ loading rate

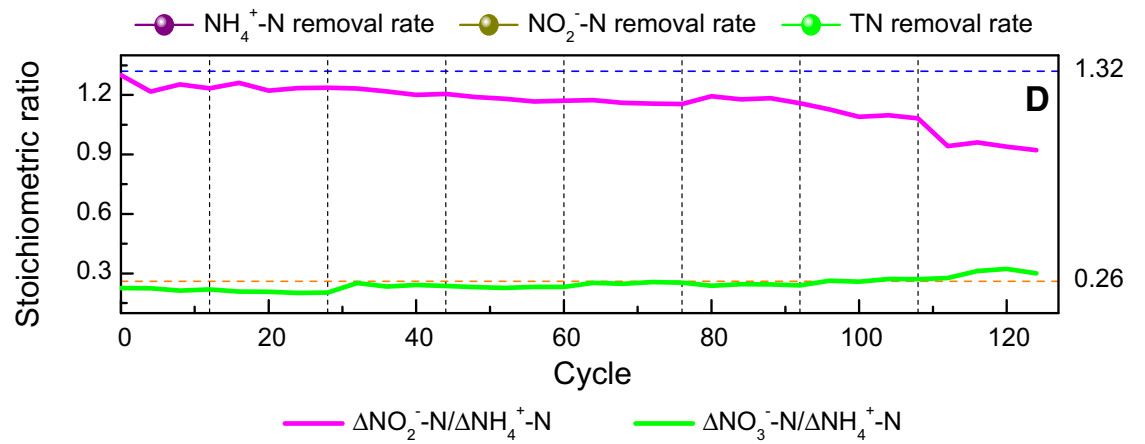

$\Delta \mathrm{NO}_{3}{ }^{-}-\mathrm{N} / \Delta \mathrm{NH}_{4}{ }^{+}-\mathrm{N}$ increased upon exposure to high $\mathrm{NH}_{4}{ }^{+}-\mathrm{N}$ concentration. Decreasing influent $\mathrm{NH}_{4}{ }^{+}-\mathrm{N} /$ $\mathrm{NO}_{2}{ }^{-}$-N back to $1 / 1.32$, anammox activity completely recovered with 7 cycles' operation (data not shown). This indicated $\mathrm{NH}_{4}{ }^{+}-\mathrm{N}$ inhibition on anammox was reversible process and high $\mathrm{NH}_{4}{ }^{+}-\mathrm{N}$ content would not damage the internal structure of AnAOB. It was also consistent with previous report that the inhibition was reversible though it was time-consuming (Zhang et al. 2016).

Many scholars had thought that the actual inhibitor to anammox was FA (Aktan et al. 2012; Dapena-Mora 
Table 2 Comparison of anammox activity resulting from $\mathrm{NH}_{4}{ }^{+}-\mathrm{N}$ effect

\begin{tabular}{llllll}
\hline Reactor & Operation mode & $\mathrm{T}\left({ }^{\circ} \mathrm{C}\right) / \mathrm{pH}$ & $\mathrm{NH}_{4}{ }^{+}-\mathrm{N} /(\mathrm{mg} / \mathrm{L})$ & Inhibition/\% & References \\
\hline SBR & - & - & 1000 & No inhibition & Strous et al. (1999) \\
Vials & Batch & $30 / 7.8$ & 770 & -50 & Dapena-Mora et al. (2007) \\
UASB & Continuous & $(35 \pm 1) / 6.8$ & 1000 & No inhibition & Tang et al. (2010) \\
Serum flacks & Batch & $35 / 7.9$ & $>500^{\mathrm{a}}$ & Inhibition & Zhang et al. (2016) \\
Serum flasks & Batch & $(30 \pm 2) /(7.4-7.5)$ & 616 & $-16^{\mathrm{b}}$ & Carvajal-Arroyo et al. (2013) \\
Serum flasks & Batch & $(30 \pm 2) /(7.4-7.5)$ & 616 & $-34^{\mathrm{c}}$ & Carvajal-Arroyo et al. (2013) \\
Up-flow fixed-bed & Continuous & $34 /$ & $1500^{\mathrm{d}}$ & No inhibition & Aktan et al. (2012) \\
SBR & Continuous & $35 / 7.5$ & 786 & -50 & Present research \\
\hline
\end{tabular}

${ }^{\text {a }}$ The inhibitory threshold concentration

${ }^{\mathrm{b}}$ The granular anammox enrichment culture (GEC)

${ }^{\mathrm{c}}$ The suspended anammox enrichment culture (SEC)

${ }^{\mathrm{d}}$ The threshold concentration of $\mathrm{NH}_{4}{ }^{+}-\mathrm{N}$ inhibition

et al. 2007; Fernandez et al. 2012). However, the threshold of FA concentration was variable. FA could penetrate through AnAOB cell membrane, which was toxic to anammox activity (Gallert and Winter 1997). In addition, FA could also neutralize membrane potential and resulted in cell death (Jaroszynski et al. 2012). Sludge concentration was also a key factor nitrogen removal performance. High biomass concentration in reactor could strengthen tolerance to $\mathrm{NH}_{4}{ }^{+}$$\mathrm{N}$ inhibition. In addition, controlling $\mathrm{pH}$ at a relatively low value could also beneficial for tolerance resulting from $\mathrm{NH}_{4}{ }^{+}-\mathrm{N}$ inhibition. With high $\mathrm{NH}_{4}{ }^{+}-\mathrm{N} / \mathrm{NO}_{2}{ }^{-}-$ $\mathrm{N}$, the excess of $\mathrm{NH}_{4}{ }^{+}-\mathrm{N}$ and the deficiency of nitrite resulted in poor nitrogen removal performance. Partial nitritation/anammox process was much better than single anammox process. The excessive ammonium could be oxidized to nitrite at partial nitritation process. Not only $\mathrm{NH}_{4}{ }^{+}-\mathrm{N}$ concentration decreased, but also $\mathrm{NO}_{2}{ }^{-}-\mathrm{N}$ was produced for further anammox process.

\section{Influent $\mathrm{NO}_{3}{ }^{-}-\mathrm{N}^{-} \mathrm{NH}_{4}{ }^{+}-\mathrm{N}$}

Nitrate was the product of anammox process, and it was necessary to explore nitrate effect on anammox process. Nitrogen removal performance of $\mathrm{R} 3$ was presented in Fig. 4. When influent $\mathrm{NO}_{3}{ }^{-}-\mathrm{N} / \mathrm{NH}_{4}{ }^{+}-\mathrm{N}$ was $0.5-1.5$, nitrogen removal rates slightly increased. With influent $\mathrm{NO}_{3}{ }^{-}-\mathrm{N} / \mathrm{NH}_{4}{ }^{+}-\mathrm{N}$ of $2.5-6.5, \mathrm{ARR}$ and NRR were stabilized at 0.33 and $0.40 \mathrm{~kg} /\left(\mathrm{m}^{3} \mathrm{~d}\right)$, respectively. Low influent $\mathrm{NO}_{3}{ }^{-}-\mathrm{N} / \mathrm{NH}_{4}{ }^{+}-\mathrm{N}$ did not inhibit anammox process. However, when influent $\mathrm{NO}_{3}{ }^{-}-\mathrm{N} / \mathrm{NH}_{4}{ }^{+}-\mathrm{N}$ was 9.5 , ARR and NRR decreased to 0.12 and $0.14 \mathrm{~kg} /\left(\mathrm{m}^{3} \mathrm{~d}\right)$, respectively. Influent $\mathrm{NO}_{3}{ }^{-}-\mathrm{N} / \mathrm{NH}_{4}{ }^{+}-\mathrm{N}$ higher than 6.5 would adversely affect nitrogen removal performance.

$\mathrm{IC}_{50}$ of $685 \mathrm{mg} / \mathrm{L}$ was achieved through the noncompetition inhibition model. The result was in agreement with Dapena-Mora et al. (2007) who found $\mathrm{IC}_{50}$ of $\mathrm{NO}_{3}{ }^{-}-\mathrm{N}$ inhibition was $630 \mathrm{mg} / \mathrm{L}$. The anammox activity comparison resulting from $\mathrm{NO}_{3}{ }^{-}$$\mathrm{N}$ inhibition was presented in Table 3. Although the results were not consistent due to different operation condition, they all suggested that AnAOB had high tolerance to $\mathrm{NO}_{3}{ }^{-}-\mathrm{N}$ than $\mathrm{NO}_{2}{ }^{-}-\mathrm{N}$. Decreasing influent $\mathrm{NO}_{3}{ }^{-}-\mathrm{N} / \mathrm{NH}_{4}{ }^{+}-\mathrm{N}$ back to 0 , anammox activity could completely recover with 20 cycles' operation (data not shown). The recovery period was much longer than those of $\mathrm{NO}_{2}{ }^{-}-\mathrm{N}$ and $\mathrm{NH}_{4}{ }^{+}-\mathrm{N}$ inhibition. The reversibility of nitrogen removal performance indicated that AnAOB structure was not damaged.

With regard to stoichiometric ratio, $\Delta \mathrm{NO}_{3}{ }^{-}{ }^{-\mathrm{N}} /$ $\Delta \mathrm{NH}_{4}{ }^{+}-\mathrm{N}$ kept stable throughout the whole process. However, $\Delta \mathrm{NO}_{2}{ }^{-}-\mathrm{N} / \Delta \mathrm{NH}_{4}{ }^{+}-\mathrm{N}$ slightly decreased at high $\mathrm{NO}_{3}{ }^{-}-\mathrm{N} / \mathrm{NH}_{4}{ }^{+}-\mathrm{N}$. As reported by Kartal et al. (2007), the produced $\mathrm{NO}_{3}{ }^{-}-\mathrm{N}$ could be transformed into $\mathrm{NO}_{2}{ }^{-} \mathrm{N}$ by AnAOB since they had the ability to reduce $\mathrm{NO}_{3}{ }^{-} \mathrm{N}$ to $\mathrm{NO}_{2}{ }^{-} \mathrm{N}$. The osmotic pressure variation resulting from high salt concentration $\left(\mathrm{KNO}_{3}\right)$ might weaken nitrogen removal performance (Li et al. 2016). In view of low nitrogen removal at high influent $\mathrm{NO}_{3}{ }^{-}-\mathrm{N} / \mathrm{NH}_{4}{ }^{+}-\mathrm{N}$, single anammox 
Fig. 4 Nitrogen removal performance with different influent $\mathrm{NO}_{3}{ }^{-}-\mathrm{N} / \mathrm{NH}_{4}{ }^{+}-\mathrm{N}$ : a concentrations of three nitrogen species in influent and effluent; $\mathbf{b}$ nitrogen removal efficiency; c loading and removal rates of $\mathrm{NH}_{4}{ }^{+}-\mathrm{N}$ and $\mathrm{NO}_{2}{ }^{-}-\mathrm{N}$; d stoichiometric ratio. (Color figure online)
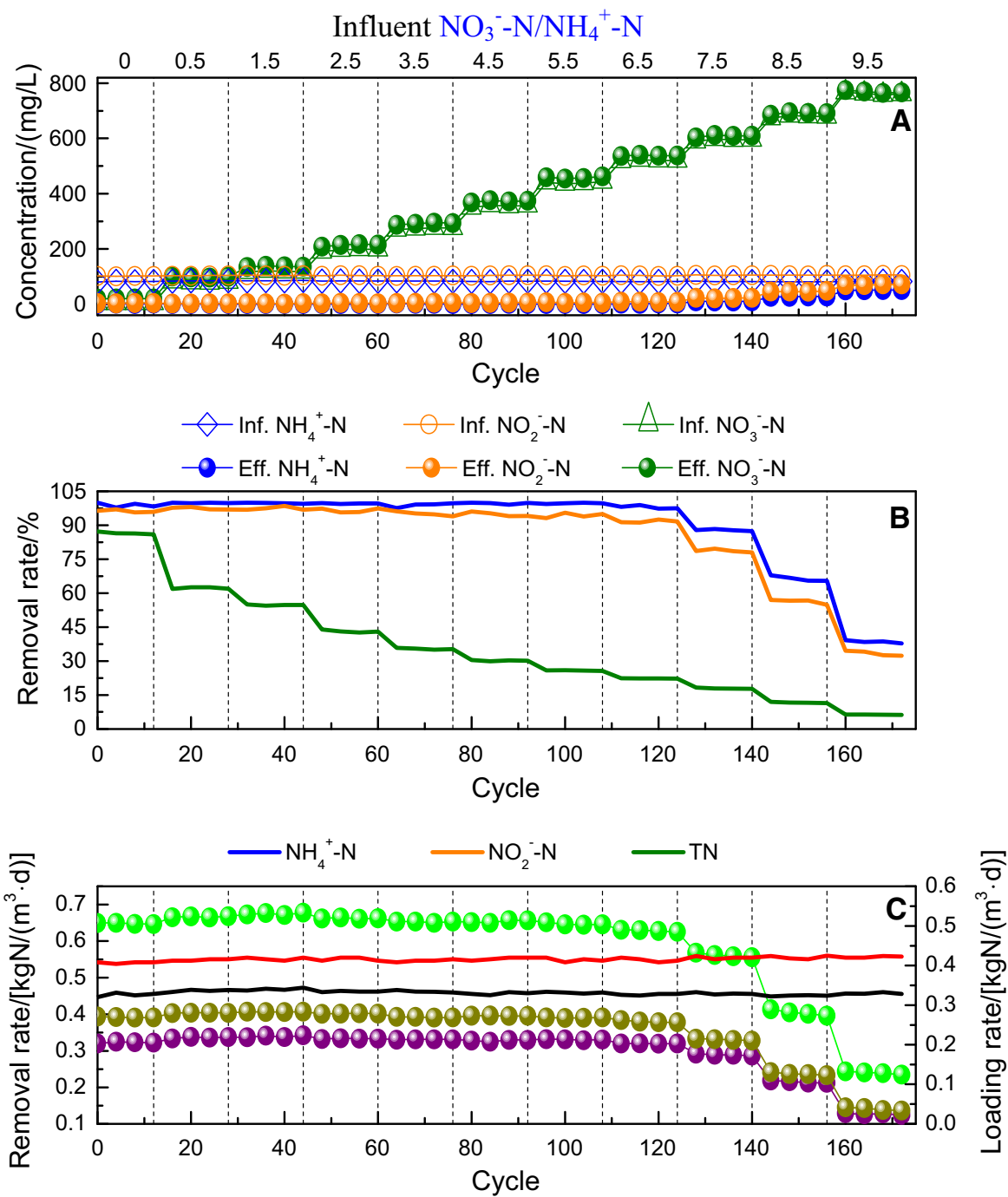

$\longrightarrow \mathrm{NH}_{4}^{+}-\mathrm{N}$ loading rate $\longrightarrow \mathrm{NO}_{2}^{-}-\mathrm{N}$ loading rate

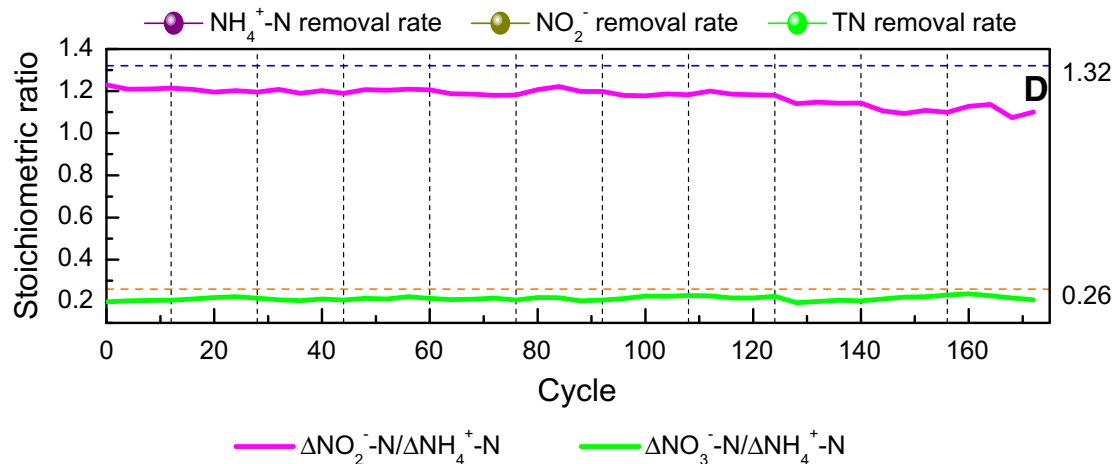


Table 3 Comparison of anammox activity resulting from $\mathrm{NO}_{3}{ }^{-}-\mathrm{N}$ effect

\begin{tabular}{llllll}
\hline Reactor & Operation mode & $\mathrm{T}\left({ }^{\circ} \mathrm{C}\right) / \mathrm{pH}$ & $\mathrm{NO}_{3}{ }^{-}-\mathrm{N} /(\mathrm{mg} / \mathrm{L})$ & Inhibition/\% & References \\
\hline SBR & - & - & 1000 & No inhibition & Strous et al. (1999) \\
Serum flasks & Batch & $(30 \pm 2) /(7.4-7.5)$ & $77-287$ & $-(40-50)^{\mathrm{a}}$ & Carvajal-Arroyo et al. (2013) \\
Serum flasks & Batch & $(30 \pm 2) /(7.4-7.5)$ & $77-287$ & $-(15-20)^{\mathrm{b}}$ & Carvajal-Arroyo et al. (2013) \\
Serum bottles & Batch & $(30 \pm 2) /-$ & 99.4 & -25 & Li et al. (2016) \\
Vials & Batch & $30 / 7.8$ & 630 & -50 & Dapena-Mora et al. (2007) \\
SBR & Continuous & $35 / 7.5$ & 685 & -50 & Present research \\
\hline
\end{tabular}

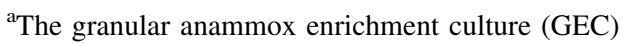

${ }^{\mathrm{b}}$ The suspended anammox enrichment culture (SEC)

technology was not suitable to treat the wastewater. Simultaneous denitrification/anammox process could be a better choice.

Nitrogen removal performance with nitrogen loading shock

To evaluate the nitrogen removal performance with substrate loading rate, influent $\mathrm{NO}_{2}{ }^{-}-\mathrm{N}$ and $\mathrm{NH}_{4}{ }^{+}-\mathrm{N}$ were simultaneously added with the ratio of 1.32 . The results were presented in Fig. 5. Both NRR and ARR increased when influent $\mathrm{NO}_{2}{ }^{-}-\mathrm{N}$ and $\mathrm{NH}_{4}{ }^{+}-\mathrm{N}$ were not more than 145 and $110 \mathrm{mg} / \mathrm{L}$, respectively. TNRR arrived at $0.9 \mathrm{~kg} /\left(\mathrm{m}^{3} \mathrm{~d}\right)$. With $\mathrm{NO}_{2}{ }^{-}-\mathrm{N}$ and $\mathrm{NH}_{4}{ }^{+}-\mathrm{N}$ were added further, both NRR and ARR decreased. However, they recovered with 10 cycles' operation. When influent $\mathrm{NH}_{4}{ }^{+}-\mathrm{N}$ was $170 \mathrm{mg} / \mathrm{L}$, ARR was about $0.57 \mathrm{~kg} /\left(\mathrm{m}^{3} \mathrm{~d}\right)$ which was $63 \%$ higher than that at $85 \mathrm{mg} / \mathrm{L} \mathrm{NH}_{4}{ }^{+}-\mathrm{N}$. AnAOB could gradually adapt to high nitrogen loading rate.

Anammox performance was unstable at high nitrogen loading rate, and sludge floatation occurred. Similar result was also observed by previous studies (Chen et al. 2010; Strous et al. 1997). The sludge floatation not only decreased sludge retention time but also damaged the system stability. It became an important problem when nitrogen loading rate was enhanced. The granular flotation caused washout of AnAOB and deteriorate anammox process. However, stoichiometric ratios were kept stable throughout the whole operation. Anammox process still dominated the reactor. Decreasing the loading rate back to initial state, seven cycles were needed to alleviate sludge floating.
Sludge size was also analyzed and the result was presented in Fig. 6. The diameter of sludge (sampled on 5th cycle) was $0-4.5 \mathrm{~mm}$, and the mean diameter was $1.58 \mathrm{~mm}$. However, the diameter of sludge (sampled on 35th cycle) was larger and the mean diameter was $2.25 \mathrm{~mm}$. The larger granular sludge formed at high nitrogen loading rate was easier to float. Chen et al. (2010) indicated that the entrapped gas bubble was real reason for granule floatation. Mechanical breakage of granular sludge might be an effective method to solve sludge floatation (Chen et al. 2010; Yoda and Nishimura, 1997). The floating sludge in this work occurred at loading rate of $1.45 \pm 0.02 \mathrm{~kg} /\left(\mathrm{m}^{3} \mathrm{~d}\right)$ which was much lower than Chen et al. (2010). This might be attributed to low inorganic carbon source $\left(\mathrm{KHCO}_{3}\right)$ and shortage of other nutrients.

\section{Kinetic analysis}

The inhibitory threshold concentration of $\mathrm{NO}_{2}{ }^{-}-\mathrm{N}$ was lower than $\mathrm{NH}_{4}{ }^{+}-\mathrm{N}$ and $\mathrm{NO}_{3}{ }^{-}-\mathrm{N}$. AnAOB was more sensitive to $\mathrm{NO}_{2}{ }^{-}-\mathrm{N}$ inhibition than $\mathrm{NH}_{4}{ }^{+}-\mathrm{N}$ and $\mathrm{NO}_{3}{ }^{-}$-N. In order to describe and predict anammox performance, $\mathrm{NO}_{2}{ }^{-}-\mathrm{N}$ inhibition characteristics were analyzed by kinetic models. The experimental data and simulated results were presented in Fig. 7 and the parameters predicted by different models were listed in Table 4. In terms of $\mathrm{R}^{2}$, Han-Levenspiel model, Luong model and Tseng-Wayman model could effectively simulated $\mathrm{NO}_{2}{ }^{-}-\mathrm{N}$ inhibition on anammox process. Although the Haldane model, Aiba model and Edwards model were widely used in substrate inhibition (Chen et al. 2011; Jin et al. 2013; De Prá et al. 2016), they were not suitable to use in this work. The 
Fig. 5 Nitrogen removal performance with different substrate loading rate: a concentrations of three nitrogen species in influent and effluent; $\mathbf{b}$ nitrogen removal efficiency; c loading and removal rates of $\mathrm{NH}_{4}{ }^{+}-\mathrm{N}$ and $\mathrm{NO}_{2}{ }^{-}-\mathrm{N}$; d stoichiometric ratio. (Color figure online)
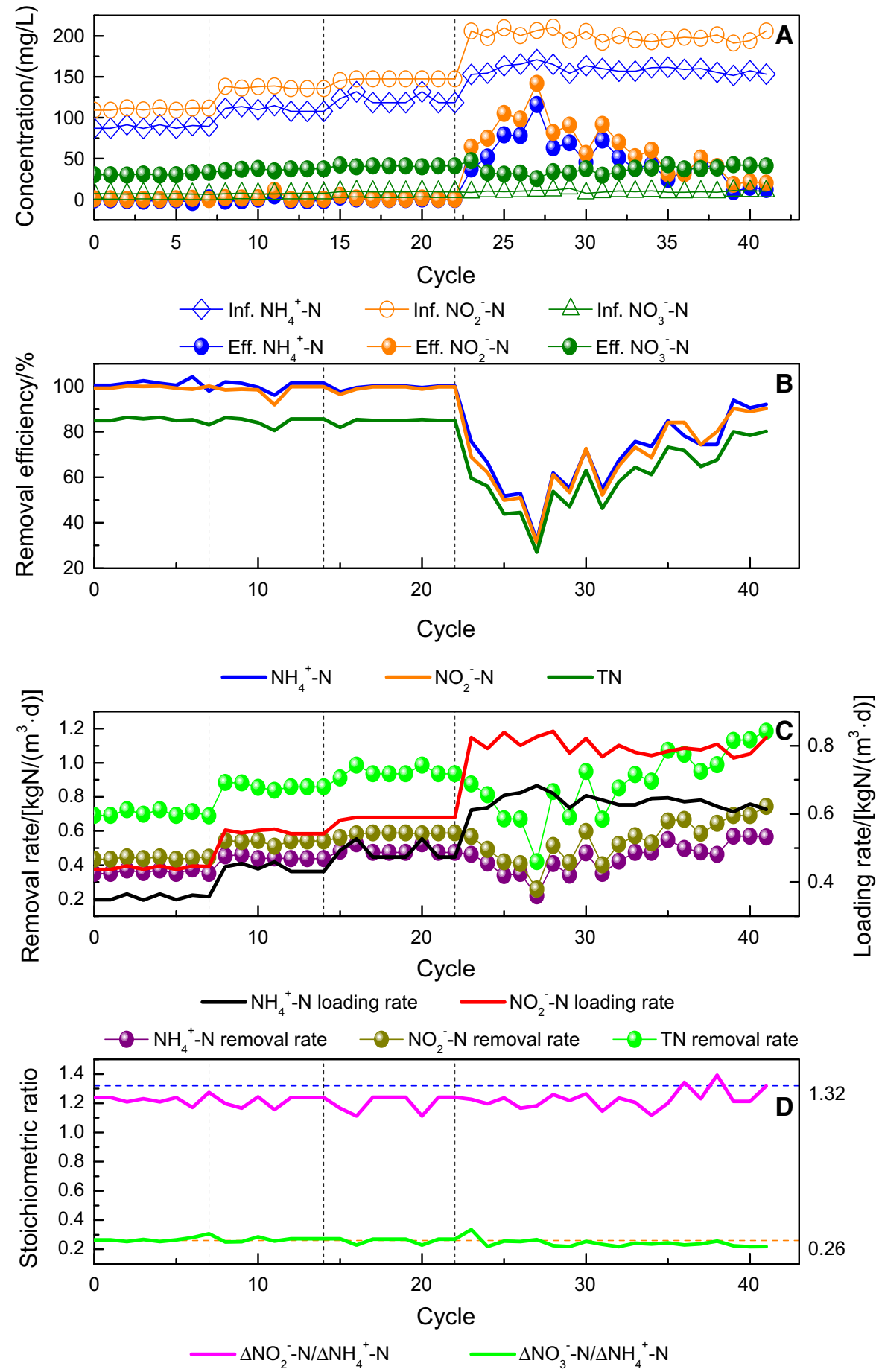

low $\mathrm{R}^{2}$ values of Haldane model and Aiba model also occurred in previous report (Niu et al. 2016). With regard to Tseng-Wayman model, the predicated $r_{\max }$ was only 0.16 . It was not consistent with the experimental data in present research. As a result, the Han-Levenspiel model and Luong model were more suitable to simulate nitrite inhibition than others. 

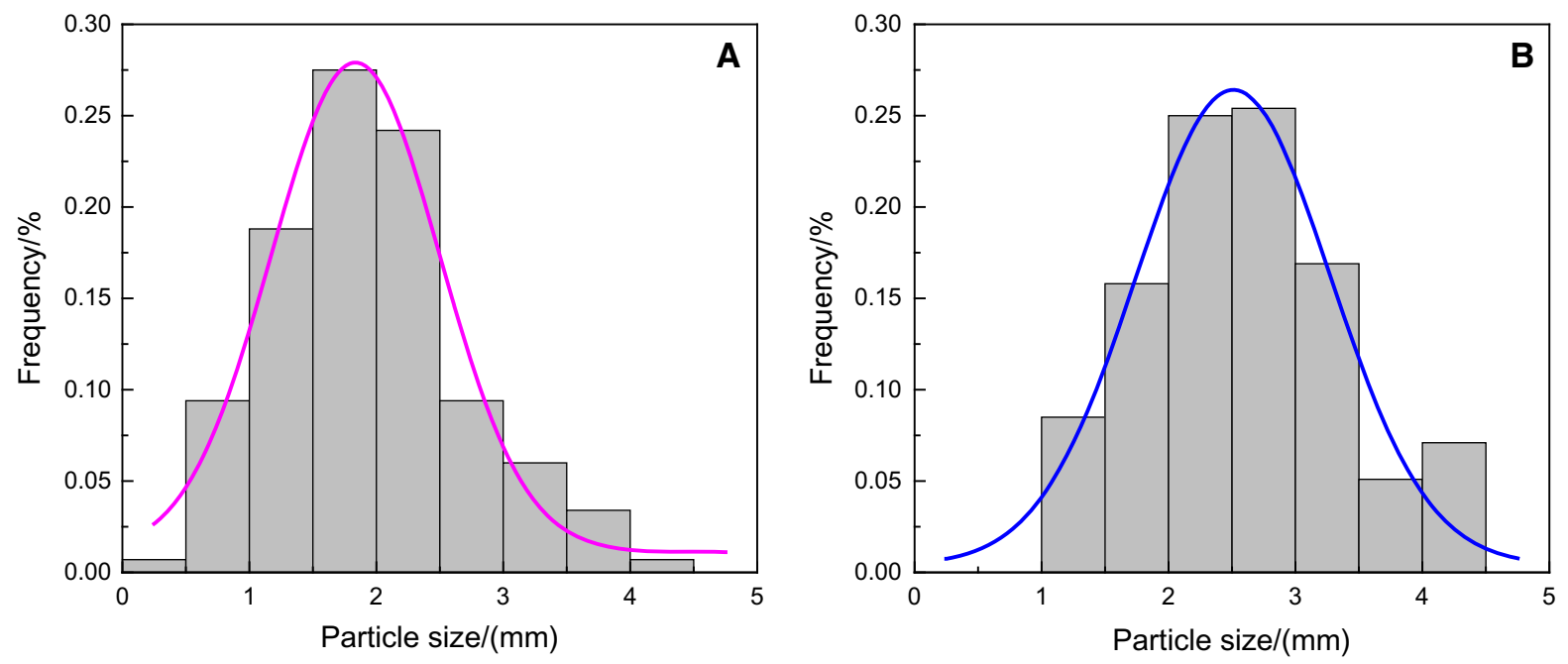

Fig. 6 Sludge particle size distribution: a sludge sampled on 5th cycle; b sludge sampled on 35th cycle

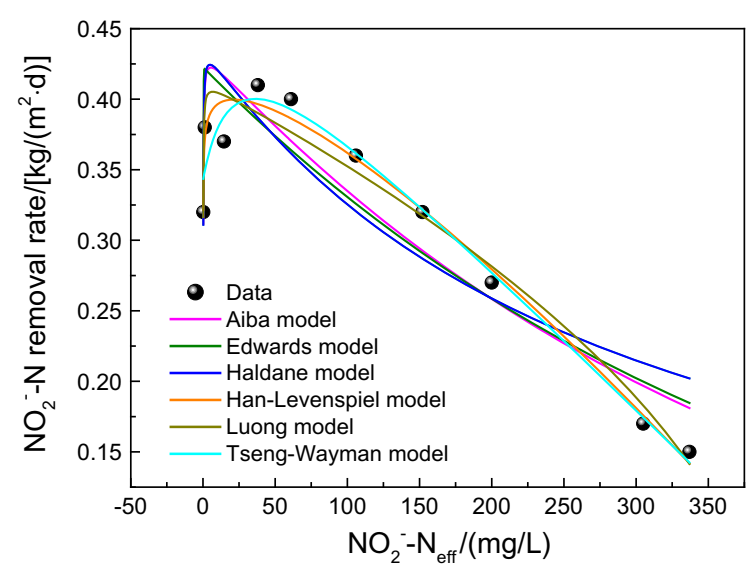

Fig. 7 Kinetic simulation by different models. (Color figure online)
AIC was an effective measurement to evaluate model appropriateness (Akaike 1974). It estimated the quality of each model by relative value, and the lowest AIC value suggested the most appropriate model. The AIC also dealt with the trade-off between appropriateness of model and complexity of model (assessed by parameter number) (De Prá et al. 2016). The analysis of AIC for different models used in nitrite inhibition was presented in Fig. 8. The AIC values of Han-Levenspiel model and Luong model were - 50 and -46 , respectively. This indicated that the HanLevenspiel model was more accurate than the Luong model. In addition, the F-Value was about 700, which suggested appropriateness in describing nitrogen removal performance. Based on the analyses above, the Han-Levenspiel model was the best one to describe the nitrite inhibition on anammox process.

Table 4 Simulated parameters acquired through different kinetic models

\begin{tabular}{llllllll}
\hline Models & \multicolumn{7}{l}{ Models parameters } \\
\cline { 2 - 7 } & $\begin{array}{l}\mathrm{r}_{\max }[\mathrm{kg} / \\
\left.\left(\mathrm{m}^{3} \mathrm{~d}\right)\right]\end{array}$ & $\begin{array}{l}\mathrm{K}_{\mathrm{S}}(\mathrm{mg} / \\
\mathrm{L})\end{array}$ & $\begin{array}{l}\mathrm{K}_{\mathrm{I}}\left(\mathrm{S}_{\mathrm{m}}\right) \\
(\mathrm{mg} / \mathrm{L})\end{array}$ & $\mathrm{n}$ & $\mathrm{m}$ & $\mathrm{R}^{2}$ & Equations \\
\hline Aiba & 0.43 & 0.08 & 384.89 & - & - & 0.8714 & $\mathrm{y}=0.43 \mathrm{x} /(0.08+\mathrm{x}) \times \exp (-\mathrm{x} / 384.89)$ \\
Edwards & 0.42 & 0.14 & 406.82 & - & - & 0.8421 & $\mathrm{y}=0.42[\exp (-\mathrm{x} / 406.82)-\exp (-\mathrm{x} / 0.14)]$ \\
Haldane & 0.44 & 0.08 & 287.77 & - & - & 0.7903 & $\mathrm{y}=0.44 \mathrm{x} /\left(\mathrm{x}+0.08+\mathrm{x}^{2} / 287.77\right)$ \\
$\begin{array}{l}\text { Han- } \\
\text { Levenspiel }\end{array}$ & 0.39 & 0.02 & 462.35 & 1.22 & 0.97 & 0.9647 & $\mathrm{y}=0.39 \mathrm{x}\left[1-(\mathrm{x} / 462.35)^{1.22}\right] /[\mathrm{x}+0.06(1-\mathrm{x} /$ \\
$\begin{array}{l}\text { Luong } \\
\text { Tseng- }\end{array}$ & 0.41 & 0.06 & 387.89 & 0.53 & - & 0.9468 & $\mathrm{y}=0.41 \mathrm{x} /(\mathrm{x}+0.06) \times(1-\mathrm{x} / 387.89)^{0.53}$ \\
$\quad$ Wayman & 0.16 & 23.37 & 333.51 & - & 0.01 & 0.9585 & $\mathrm{y}=0.16[\mathrm{x} /(23.37+\mathrm{x})]-0.01(\mathrm{x}-333.51)$ \\
\hline
\end{tabular}




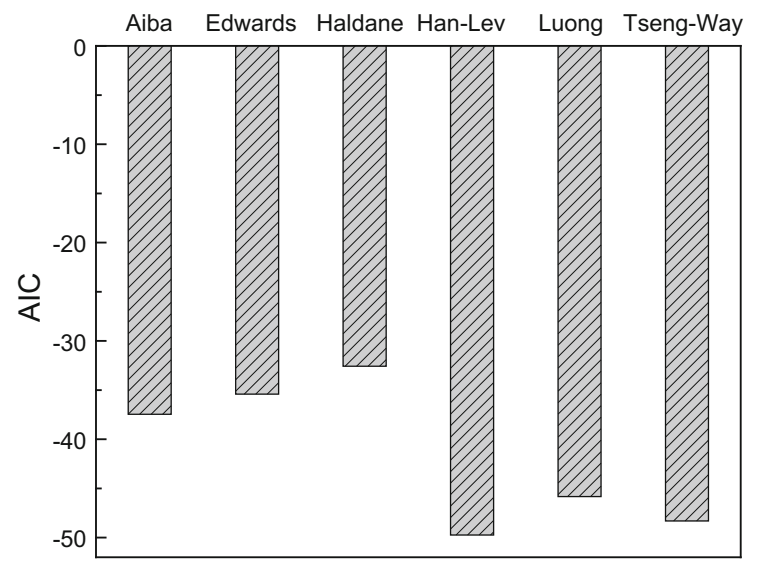

Fig. 8 AIC analysis of different kinetic models

Concerning the parameters achieved from HanLevenspiel model, the $r_{\text {max }}$ value was $0.39 \mathrm{~kg} /\left(\mathrm{m}^{3} \mathrm{~d}\right)$, which was lower than previous reports (Jin et al. 2013; Niu et al. 2016). The discrepancy between the results could be attributed to low sludge concentration in this work. The half saturation constant $\left(\mathrm{K}_{\mathrm{s}}\right)$ could represent bacteria affinity for $\mathrm{NO}_{2}{ }^{-}-\mathrm{N}$, and it was only $0.02 \mathrm{mg} /$ L. This agreed with Strous et al. (1999) who found the affinity constant for $\mathrm{NO}_{2}{ }^{-}-\mathrm{N}$ was less than $0.1 \mathrm{mg} / \mathrm{L}$. The predicted $\mathrm{S}_{\mathrm{m}}$ was $462 \mathrm{mg} / \mathrm{L}$ and it suggested the endurance capacity of $\mathrm{NO}_{2}^{-}-\mathrm{N}$ in present research. The higher value of $\mathrm{S}_{\mathrm{m}}$ meant the stronger endurance capacity of $\mathrm{NO}_{2}{ }^{-}-\mathrm{N}$. It indicated that anammox reaction did not occur when $\mathrm{NO}_{2}{ }^{-}-\mathrm{N}$ concentration was higher than $462 \mathrm{mg} / \mathrm{L}$ in this work.

\section{Conclusions}

SBRs were employed to study the effect of influent substrate ratio on anammox process. With influent $\mathrm{NO}_{2}{ }^{-}{ }^{-} \mathrm{N} / \mathrm{NH}_{4}{ }^{+}-\mathrm{N}$ no more than 2.0, TNRR increased whereas ARR stabilized at $0.32 \mathrm{~kg} /\left(\mathrm{m}^{3} \mathrm{~d}\right)$. Anammox activity was inhibited at high $\mathrm{NO}_{2}{ }^{-}-\mathrm{N} / \mathrm{NH}_{4}{ }^{+}-\mathrm{N}$. When $\mathrm{NO}_{2}{ }^{-}{ }^{-} \mathrm{N} / \mathrm{NH}_{4}{ }^{+}-\mathrm{N}$ was $4.5, \Delta \mathrm{NO}_{2}{ }^{-}-\mathrm{N} / \Delta \mathrm{NH}_{4}{ }^{+}-\mathrm{N}$ and $\Delta \mathrm{NO}_{3}{ }^{-}-\mathrm{N} / \Delta \mathrm{NH}_{4}{ }^{+}-\mathrm{N}$ were 1.98 and 0.68 , respectively. Both were higher than theoretical value. When influent $\mathrm{NH}_{4}{ }^{+}-\mathrm{N} / \mathrm{NO}_{2}{ }^{-} \mathrm{N}$ was more than 5.0, anammox activity was inhibited. $\Delta \mathrm{NO}_{2}{ }^{-}-\mathrm{N} / \Delta \mathrm{NH}_{4}{ }^{+}-\mathrm{N}$ slightly decreased with increasing $\mathrm{NH}_{4}{ }^{+}-\mathrm{N} / \mathrm{NO}_{2}{ }^{-}-\mathrm{N}$. With influent $\mathrm{NO}_{3}{ }^{-}-\mathrm{N} / \mathrm{NH}_{4}{ }^{+}-\mathrm{N}$ of $2.5-6.5, \mathrm{ARR}$ and NRR were stabilized at 0.33 and $0.40 \mathrm{~kg} /\left(\mathrm{m}^{3} \mathrm{~d}\right)$, respectively. Nitrogen removal was worsened when influent $\mathrm{NO}_{3}{ }^{-}-\mathrm{N} / \mathrm{NH}_{4}{ }^{+}-\mathrm{N}$ was higher than 6.5. AnAOB could gradually adapt to high nitrogen loading rate. The inhibitory threshold concentration of $\mathrm{NO}_{2}{ }^{-}-\mathrm{N}$ was lower than $\mathrm{NH}_{4}{ }^{+}-\mathrm{N}$ and $\mathrm{NO}_{3}{ }^{-}-\mathrm{N}$. AnAOB was more sensitive to $\mathrm{NO}_{2}{ }^{-}-\mathrm{N}$ than $\mathrm{NH}_{4}{ }^{+}-\mathrm{N}$ and $\mathrm{NO}_{3}{ }^{-}-\mathrm{N}$. The Han-Levenspiel and Luong model could be applied to simulate $\mathrm{NO}_{2}{ }^{-} \mathrm{N}$ inhibition, and the Han-Levenspiel model was better. The predicted $\mathrm{S}_{\mathrm{m}}$ was $462 \mathrm{mg} / \mathrm{L}$, which indicated that anammox reaction did not occur when $\mathrm{NO}_{2}{ }^{-}-\mathrm{N}$ concentration was higher than $462 \mathrm{mg} / \mathrm{L}$.

Acknowledgements The work was financially supported by National Natural Scientific Foundation (41376016), Shandong Provincial Natural Science Foundation (BS2015HZ007) and Shandong Province Higher Educational Science and Technology Program (J15LC61). The authors would like to thank the editor and anonymous reviewers for their editing and review.

\section{References}

Aiba S, Shoda M, Nagatani M (1968) Kinetics of product inhibition in alcohol fermentation. Biotechnol Bioeng 10(6):845-864

Akaike H (1974) A new look at the statistical model identification. IEEE Trans Autom Control 19(6):716-723

Aktan CK, Yapsakli K, Mertoglu B (2012) Inhibitory effects of free ammonia on Anammox bacteria. Biodegradation 23(5):751-762

Almeida JS, Júlio SM, Reis MAM, Carrondo MJT (1995) Nitrite inhibition of denitrification by Pseudomonas fluorescens. Biotechnol Bioeng 46(3):194-201

APHA (1998) Standard methods for water and wastewater examination. American Public Health Association, Washington

Bettazzi E, Caffaz S, Vannini C, Lubello C (2010) Nitrite inhibition and intermediates effects on Anammox bacteria: a batch-scale experimental study. Process Biochem 45(4):573-580

Carvajal-Arroyo JM, Sun W, Sierra-Alvarez R, Field JA (2013) Inhibition of anaerobic ammonium oxidizing (anammox) enrichment cultures by substrates, metabolites and common wastewater constituents. Chemosphere 91(1):22-27

Carvajal-Arroyo JM, Puyol D, Li G, Lucero-Acuña A, SierraÁlvarez R, Field JA (2014a) Pre-exposure to nitrite in the absence of ammonium strongly inhibits anammox. Water Res 48:52-60

Carvajal-Arroyo JM, Puyol D, Li G, Sierra-Álvarez R, Field JA (2014b) The role of $\mathrm{pH}$ on the resistance of resting- and active anammox bacteria to $\mathrm{NO}_{2}{ }^{-}$inhibition. Biotechnol Bioeng 111(10):1949-1956

Chen J, Ji Q, Zheng P, Chen T, Wang C, Mahmood Q (2010) Floatation and control of granular sludge in a high-rate anammox reactor. Water Res 44(11):3321-3328 
Chen T, Zheng P, Shen L, Ding S, Mahmood Q (2011) Kinetic characteristics and microbial community of AnammoxEGSB reactor. J Hazard Mater 190(1):28-35

Cho S, Takahashi Y, Fujii N, Yamada Y, Satoh H, Okabe S (2010) Nitrogen removal performance and microbial community analysis of an anaerobic up-flow granular bed anammox reactor. Chemosphere 78(9):1129-1135

Dapena-Mora A, Fernández I, Campos JL, Mosquera-Corral A, Méndez R, Jetten MSM (2007) Evaluation of activity and inhibition effects on anammox process by batch tests based on the nitrogen gas production. Enzyme Microb Technol 40(4):859-865

De Prá MC, Kunz A, Bortoli M, Scussiato LA, Coldebella A, Vanotti M, Soares HM (2016) Kinetic models for nitrogen inhibition in ANAMMOX and nitrification process on deammonification system at room temperature. Bioresour Technol 202:33-41

Edwards VH (1970) The influence of high substrate concentrations on microbial kinetics. Biotechnol Bioeng 12(5):679-712

Egli K, Fanger U, Alvarez PJJ, Siegrist H, van der Meer JR, Zehnder AJB (2001) Enrichment and characterization of an anammox bacterium from a rotating biological contactor treating ammonium-rich leachate. Arch Microbiol 175(3):198-207

Fernandez I, Dosta J, Fajardo C, Campos JL, Mosquera-Corral A, Mendez R (2012) Short- and long-term effects of ammonium and nitrite on the Anammox process. J Environ Manag 95(Suppl):S170-S174

Gallert C, Winter J (1997) Mesophilic and thermophilic anaerobic digestion of source-sorted organic wastes: effect of ammonia on glucose degradation and methane production. Appl Microbiol Biotechnol 48(3):405-410

Han K, Levenspiel O (1988) Extended monod kinetics for substrate, product, and cell inhibition. Biotechnol Bioeng 32(4):430-447

Isaka K, Sumino T, Tsuneda S (2007) High nitrogen removal performance at moderately low temperature utilizing anaerobic ammonium oxidation reactions. J Biosci Bioeng 103(5):486-490

Jaroszynski LW, Cicek N, Sparling R, Oleszkiewicz JA (2011) Importance of the operating $\mathrm{pH}$ in maintaining the stability of anoxic ammonium oxidation (anammox) activity in moving bed biofilm reactors. Bioresour Technol 102(14):7051-7056

Jaroszynski LW, Cicek N, Sparling R, Oleszkiewicz JA (2012) Impact of free ammonia on anammox rates (anoxic ammonium oxidation) in a moving bed biofilm reactor. Chemosphere 88(2):188-195

Jetten MSM, Cirpus I, Kartal B, van Niftrik L, van de PasSchoonen KT, Sliekers O, Haaijer S, van der Star W, Schmid M, van de Vossenberg J, Schmidt I, Harhangi H, van Loosdrecht M, Gijs Kuenen J, Op den Camp H, Strous M (2005) 1994-2004: 10 years of research on the anaerobic oxidation of ammonium. Biochem Soc T 33(1):119-123

Jin RC, Xing BS, Yu JJ, Qin TY, Chen SX (2013) The importance of the substrate ratio in the operation of the Anammox process in upflow biofilter. Ecol Eng 53(3):130-137

Kartal B, Kuypers MMM, Lavik G, Schalk J, Op den Camp HJM, Jetten MSM, Strous M (2007) Anammox bacteria disguised as denitrifiers: nitrate reduction to dinitrogen gas via nitrite and ammonium. Environ Microbiol 9(3):635-642

Kimura Y, Isaka K, Kazama F, Sumino T (2010) Effects of nitrite inhibition on anaerobic ammonium oxidation. Appl Microbiol Biotechnol 86(1):359-365

Kroiss H, Schweighofer P, Frey W, Matsche N (1992) Nitrification inhibition-a source identification method for combinedmunicipal and/or industrial wastewater treatment plants. Water Sci Technol 26(5-6):1135-1146

Lan C, Kumar M, Wang C, Lin J (2011) Development of simultaneous partial nitrification, anammox and denitrification (SNAD) process in a sequential batch reactor. Bioresour Technol 102:5514-5519

Li G, Vilcherrez D, Carvajal-Arroyo JM, Sierra-Alvarez R, Field JA (2016) Exogenous nitrate attenuates nitrite toxicity to anaerobic ammonium oxidizing (anammox) bacteria. Chemosphere 144:2360-2367

Li J, Zhu W, Dong H, Wang D (2017) Performance and kinetics of ANAMMOX granular sludge with $\mathrm{pH}$ shock in a sequencing batch reactor. Biodegradation 28:245-259

Lotti T, van der Star WRL, Kleerebezem R, Lubello C, van Loosdrecht MCM (2012) The effect of nitrite inhibition on the anammox process. Water Res 46(8):2559-2569

Luong JHT (1987) Generalization of monod kinetics for analysis of growth data with substrate inhibition. Biotechnol Bioeng 29(2):242-248

Mehl M, Daiber A, Herold S, Shoun H, Ullrich V (1999) Peroxynitrite reaction with heme proteins. Nitric Oxide 3(2):142-152

Niu Q, He S, Zhang Y, Zhang Y, Yang M, Li Y (2016) Biokinetics evaluation and batch modeling of the anammox mixed culture in UASB and EGSB reactors: batch performance comparison and kinetic model assessment. RSC Adv 6(5):3487-3500

Oshiki M, Shimokawa M, Fujii N, Satoh H, Okabe S (2011) Physiological characteristics of the anaerobic ammoniumoxidizing bacterium 'Candidatus Brocadia sinica'. Microbiology 157(6):1706-1713

Philips S, Laanbroek HJ, Verstraete W (2002) Origin, causes and effects of increased nitrite concentrations in aquatic environments. Rev Environ Sci Biotechnol 1(2):115-141

Scaglione D, Ruscalleda M, Ficara E, Balaguer MD, Colprim J (2012) Response to high nitrite concentrations of anammox biomass from two SBR fed on synthetic wastewater and landfill leachate. Chem Eng J 209(41):62-68

Strous M, van Gerven E, Zheng P, Gijs Kuenen J, Jetten MSM (1997) Ammonium removal from concentrated waste streams with the anaerobic ammonium oxidation (Anammox) process in different reactor configurations. Water Res 31(8):1955-1962

Strous M, Heijnen JJ, Gijs Kuenen J, Jetten MSM (1998) The sequencing batch reactor as a powerful tool for the study of slowly growing anaerobic ammonium-oxidizing microorganisms. Appl Microbiol Biotechnol 50(5):589-596

Strous M, Kuenen JG, Jetten MSM (1999) Key physiology of anaerobic ammonium oxidation. Appl Environ Microb 65(7):3248-3250

Tang CJ, Zheng P, Mahmood Q, Chen JW (2009) Start-up and inhibition analysis of the Anammox process seeded with anaerobic granular sludge. J Ind Microbiol Biotechnol 36(8):1093-1100 
Tang CJ, Zheng P, Hu BL, Chen JW, Wang CH (2010) Influence of substrates on nitrogen removal performance and microbiology of anaerobic ammonium oxidation by operating two UASB reactors fed with different substrate levels. J Hazard Mater 181(1):19-26

Tao Y, Gao DW, Fu Y, Wu WM, Ren NQ (2012) Impact of reactor configuration on anammox process start-up: MBR versus SBR. Bioresour Technol 104(1):73-80

Tseng MM, Wayman M (1975) Kinetics of yeast growth:inhibition-threshold substrate concentrations. Can J Microbiol 21(7):994-1003

Tsushima I, Ogasawara Y, Kindaichi T, Satoh H, Okabe S (2007) Development of high-rate anaerobic ammoniumoxidizing (anammox) biofilm reactors. Water Res 41(8):1623-1634

van de Graaf AA, de Bruijn P, Robertson LA, Jetten MSM, Kuenen JG (1996) Autotrophic growth of anaerobic ammonium-oxidizing micro-organisms in a fluidized bed reactor. Microbiology 142(8):2187-2196

van der Star WRL, Abma WR, Blommers D, Mulder JW, Tokutomi T, Strous M, Picioreanu C, van Loosdrecht MCM (2007) Startup of reactors for anoxic ammonium oxidation: experiences from the first full-scale anammox reactor in Rotterdam. Water Res 41(18):4149-4163 van Hulle SWH, Vandeweyer HJP, Meesschaert BD, Vanrolleghem PA, Dejans P, Dumoulin A (2010) Engineering aspects and practical application of autotrophic nitrogen removal from nitrogen rich streams. Chem Eng J 162(1):1-20

Wang Y, Hu X, Jiang B, Song Z, Ma Y (2016) Symbiotic relationship analysis of predominant bacteria in a lab-scale anammox UASB bioreactor. Environ Sci Pollut R 23(8):7615-7626

Yang J, Zhang L, Hira D, Fukuzaki Y, Furukawa K (2011) Highrate nitrogen removal by the Anammox process at ambient temperature. Bioresour Technol 102(2):672-676

Yoda M, Nishimura S (1997) Controlling granular, sludge floatation in UASB reactors. Water Sci Technol 36(6-7):165-173

Zhang Y, He S, Niu Q, Qi W, Li YY (2016) Characterization of three types of inhibition and their recovery processes in an anammox UASB reactor. Biochem Eng J 109:212-221

Zhu W, Li J, Dong H, Wang Dan, Zhang Peiyu (2017a) Nitrogen removal performance and operation strategy of anammox process under temperature shock. Biodegradation 28(4):261-274

Zhu W, Zhang P, Dong H, Li J (2017b) Effect of carbon source on nitrogen removal in anaerobic ammonium oxidation (anammox) process. J Biosci Bioeng 123(4):497-504 